P6X NMAH 



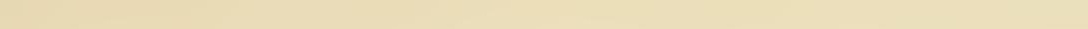







\section{CONCRETE SHIPS}

A POSSIBLE SOLUTION

- of the SHIPPING PROBLEM
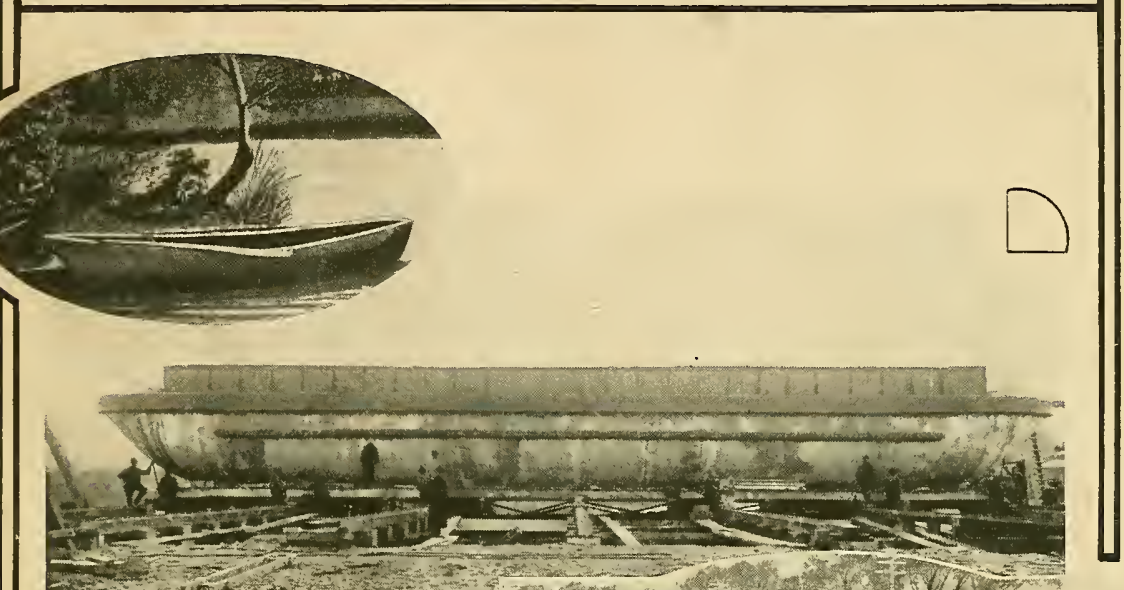

$\square=-1+-$
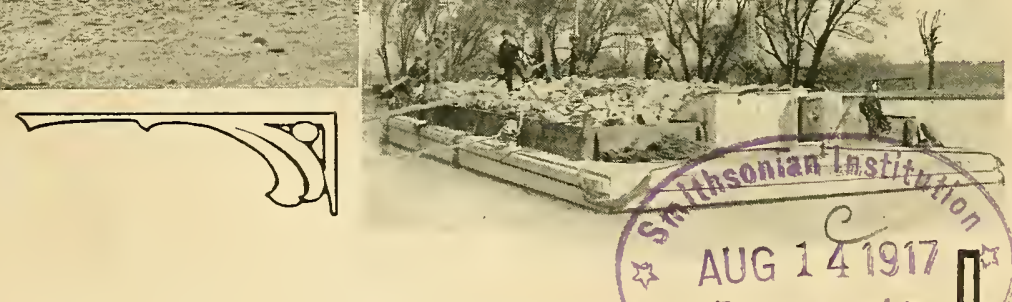

Concrete for Permanence P. $4107 \mathrm{~T}$

Published by

Portland CEMEnt Association

III West Washington Street

CHICAGO 
GHIPS, more ships, and still more ships, is the need of the hour. To supply them quickly is a military necessity. This booklet has been prepared to suggest a possible means of solving the problem. 


\section{Another Ship Resource}

The glimmer of a new hope has dawned in the shipbuilding situation. Experts are sponsoring reenforced concrete as a resource for hulls. The practicability of their suggestion is attested by the entrance of Sweden and Norway upon the construction of "stone" vessels of larger tonnage than our projected wooden ships of standardized fame. Concrete men assert that this material not only is cheap and adaptable for quick use but that it is feasible for large ships that will be indestructible by storm iceberg or torpedo. The public would like to have the Shipping Board give this material a tryout at once without losing any sleep over the fear that cement men might be enabled thereby to make a living.

There has been less soothing syrup handed out lately about the U-boat peril. Lord NORTHCLIFFe recognizes the submarine as the most serious feature of the war at present and considers the best precaution to be an ability on the part of the merchant ship to develop a speed of at least fifteen miles an hour in the danger zone. The Chamber of Commerce has issued a simultaneous appeal for speed.

One deplorable fact still stands out boldly. Ships of the most ideal type cannot be created by the waving of a wand even in the hand of our great canal builder. It could not be accomplished even if $\mathrm{Mr}$.
DENMAN should let go of the other end of the wand. The justification for wooden ships lies in the possibility of their multiplication like veritable vermin of the seas at a rate that will reduce the extermınators to impotence and despair.

So far as this argument is cogent ir the case of wooden ships it would be equally if not more applicable as regards concrete. The supply of concrete is practically inexhaustible it is highly economical and in point of rapidity of constructicn concrete ships would leave the wooden ones stranded on the stocks. Furthermore it is possible that concrete ships may be able to make as many knots an hour as steel ones.

It has been disputed that the wooden ships can be built more rapidly than the steel. Not only is machinery used to a greater extent in the construction of steel ships but the fact of their much larger size makes it likely that they can win the race in tonnage production. The factor that makes for celerity in the construction of concrete boats is that they are poured into a mould. A steel frame to be sure is requisite but they can be turned out like crockery and the moulds used indefinitely. Here is hope for the building up of an unsinkable fireproof merchant marine in half the time and at half the cost of either wood or steel.

\section{REPRINTED BY}

Portland Cement Association 111 WEST WASHINGTON STREET 



\section{CONCRETE SHIPS \\ A Possible Solution of the Shipping Problem

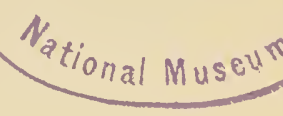

\section{WE MUST HAVE SHIPS TO WIN THIS WAR}

$\mathrm{O}$

UR cooperation with the Allies, to be most effective, requires ships.

As many as possible must immediately be built, bought or rehabilitated for active service. Men must be transported to the field of action. Ammunition, food and other necessities for their effective maintenance and operations must be supplied. Demands made for means of water transport will far exceed anything heretofore known. For many months a continuous stream of men, munitions and other supplies will reach the European battle front in volume sufficient to overwhelm every opposition.

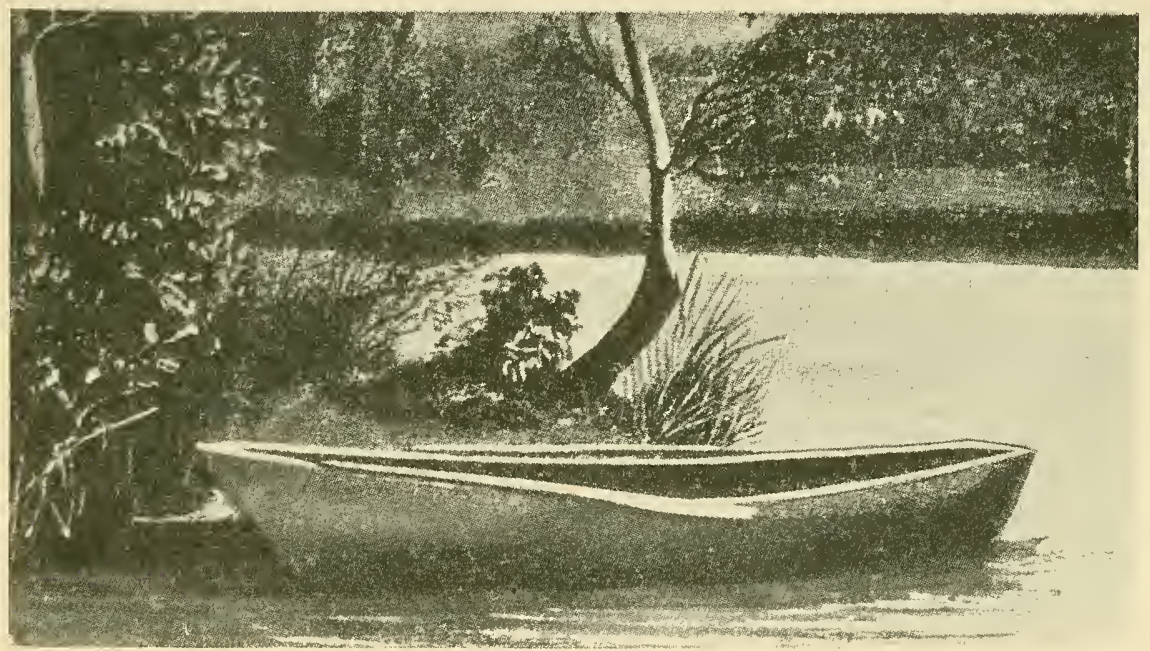

The First Concrete Boat, also the First Use of Reinforced Concrete. This Boat was Built and Patented in 1849, by M. Lambot, Carces, France.

\section{HOW MAY SHIPS BE SECURED?}

For many years other industries have been developed in this country to the neglect of our merchant marine. Dependence has been placed upon foreign shipping and shipyards for ocean transport. The shortage, both of steel and of wood, for shipbuilding needs as felt today in this country has, in part, been due to our having supplied foreign needs for materials instead of using them to build our own ships. 
Emergency requirements do not always permit choice of methods and materials. There are no large stocks of suitable lumber and timber available to meet the urgency of the present situation. Timber cannot be cut and seasoned in a day. The available supply of steel plate does not meet the present demand. These conditions increase the difficulty of speedily building an adequate number of ships. Where steel plates are available and shipyards can build steel ships, every assistance should be given them to secure materials and labor. Wood ships also should be started and rushed to completion in every yard which is able to secure the necessary materials and skilled ship labor. But all tonnage that can be produced under present methods will not completely fill today's shipping needs. Still more ships should be built.

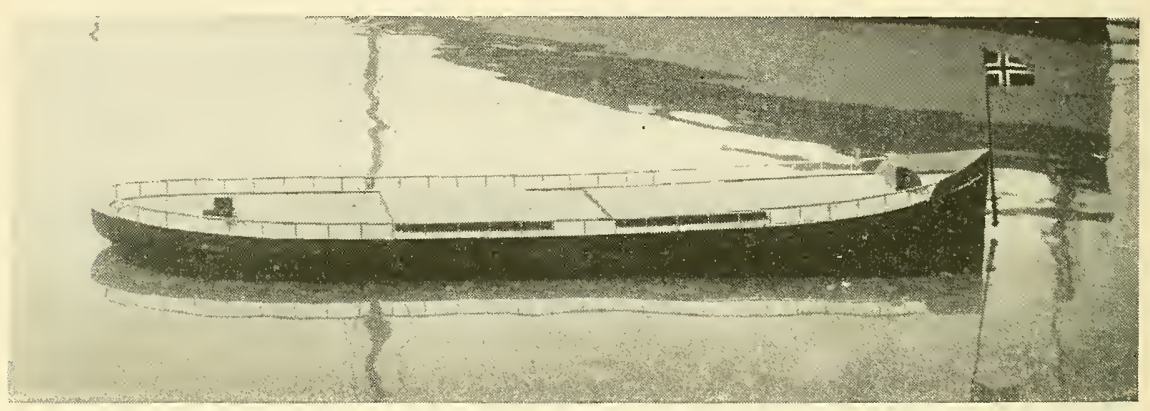

Nine-foot Model of Concrete Boat Built by Concrete Products Plant at Porsgrund, Norway. This Model was turned over to the United States Bureau of Standards, July, 1917, to enable it to study the methods of Construction. The Company which Built this Boat is now Turning Out Concrete Vessels of 200 Tons Capacity.

In 17 weeks following the initiation of Germany's unrestricted U-boat warfare in February, 350 vessels of $\mathrm{I} 600$ tons and upward were sunk. In addition, nearly 150 under 1600 tons as well as i 13 smaller craft have gone to the bottom. In replacing losses caused by this destruction, the United States Shipping Board Emergency Fleet Corporation, as announced by General Goethals, had, at the time this booklet was written (July i5, I 917 ) completed 16 ships and had contracted for 138 . This total was made up of 28 complete steel ships, 32 complete composite ships, 30 complete wooden ships, and 48 wooden hulls. At the present rate of sinking, which averages more than 20 vessels of 1600 tons and over per week, 138 ships will be sunk in 7 weeks. Any new method that will increase the capacity for shipbuilding should be adopted.

\section{WILL CONCRETE VESSELS SOLVE THE PROBLEM?}

A shipbuilding material must be found that can be quickly and readily obtained in large quantities. 
There are many reasons why concrete is a logical material for ship construction. Several of these reasons are especially applicable to the present situation:

Materials required for constructing concrete vessels are available in necessary quantities.

Little skilled labor is required.

Concrete vessels can be constructed rapidly.

Concrete ships are reasonable in cost.

Concrete ships will not burn.

Concrete vessels can be kept in constant service because there are few maintenance requirements.

Concrete ships built to supply present needs will be equally useful after the war when industry will demand shipping facilities probably even greater than at present.

Concrete has been used in every form of construction. It is a known quantity. Ships can be designed in concrete to meet every requirement.

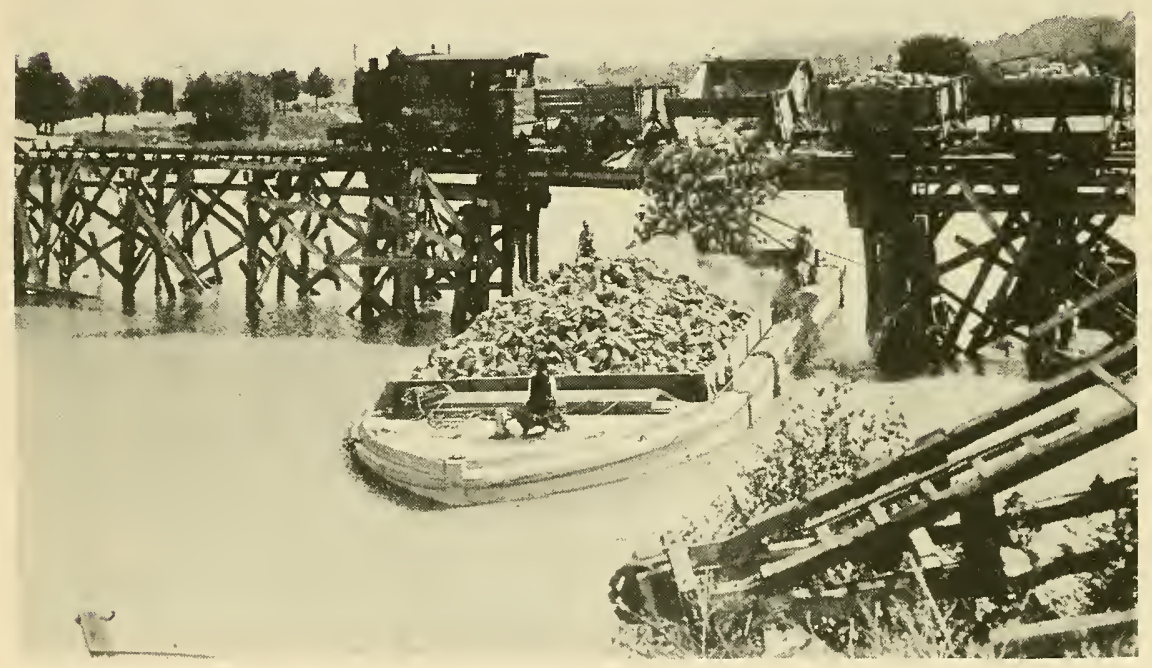

The Concrete Barge "Pioneer," Now in Use on the Welland Canal, Heavily Loaded with Stone. Dump-car Loads of Several Tons Each Being Dropped from a 12-foot Trestle into the Barge.

\section{WHAT THE PRESS IS SAYING}

Leading papers throughout the country have not been tardy in recognizing the need of immediately solving the shipping problem; nor have they overlooked the fact that concrete is likely to prove itself adaptable to the present situation.

In the Boston Evening Record of Saturday, June 30, there was a communication addressed to that paper by a Boston expert in construc- 
tion engineering setting forth claims for the concrete ship. The writer said:

"My plan makes little if any change in the outward appearance of our modern steel ship, except that the structural part of the ship is of a specially prepared emulsified concrete reinforced with a fabricated network of steel rods that bonds the ship together in every part, giving great strength and making the structure one continuous monolith. All decks, partitions, etc., are interwoven together in one continuous mass of steel and concrete. The ship has two hulls and a double bottom; the double hull runs to above the water line all around the ship. There is a space of 3 feet 0 inches between the outer and inner hull which is divided every 12 feet, making a continuous number of watertight compartments 3 feet 0 inches by 12 feet 0 inches girding every part of the ship to above the water line. In the center of this 3 feet 0 inches space is a system of fabricated steel rods looking somewhat like a heavy wire fence; the purpose of which will be explained later. This space between the double hulls and double bottom is not wasted, but being watertight, is used as storage tanks for carrying oil cargoes and for storing fuel for the ship's engines, the vessel being driven by oil engines, requiring a much smaller crew than a steam driven vessel and giving more space for freight.

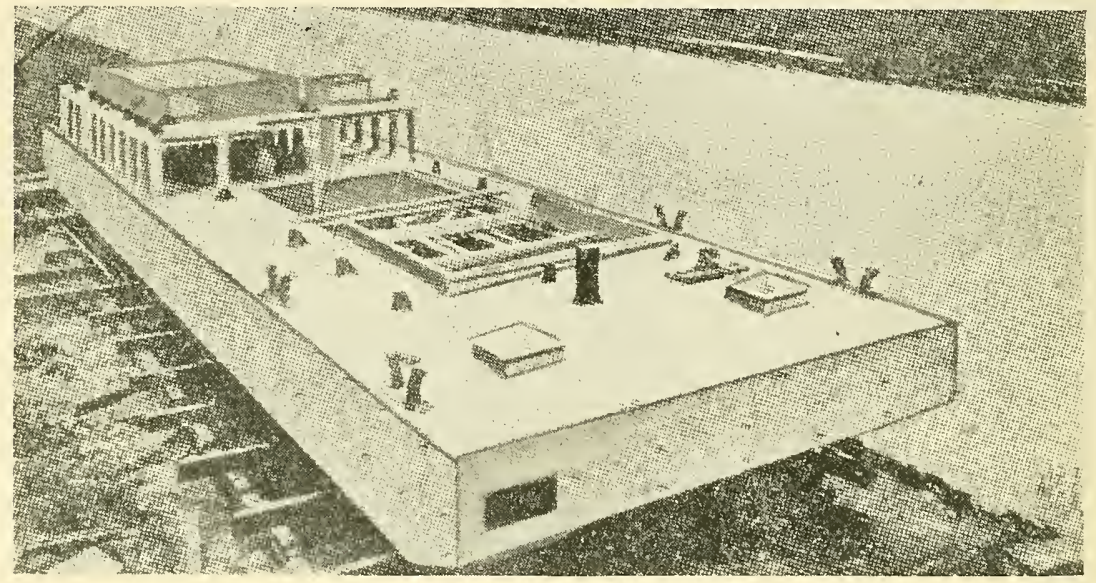

Concrete Pontoon Built for the Manchester Ship Canal Co., England, by the Yorkshire Hennebique Contracting Co., Ltd., Leeds, England.

"The designs and methods of fabricating the steel reinforcing rods are such as to make a ship strong enough to resist the heaviest sort of a gale without straining herself, yet no attempt is made in this plan to build the outer hull heavy enough to resist the explosion of a torpedo; so let us suppose such a ship is struck by a torpedo fired from an enemy submarine; the force of the explosion is so great that a hole two or three feet in diameter may be shattered in the outer hull, and now appears the use for the fabricated rods (or strong wire fence) inside the space between the two hulls.

\section{TORPEDO MADE HARMLESS}

"These rods work on the same principle as Mr. Maxim's gun silencer, they dissipate, or in other words break up the force of the explosion, at the same time they protect the walls of the inner hull from being damaged by flying pieces of the concrete; thus a section $3 \times 12$ feet is damaged and its cargo of oil is thrown against the force of the explosion, but this of itself helps to cool the hot gases caused by the explosion; each $3 \times 12$ foot section is vented at the upper deck with a hatch that opens outward to let the explosive gases escape. The torpedo has now done its worst and the ship has lost a few hundred gallons, maybe, of fuel oil, but the damage can readily be repaired in a few hours on arrival at her destination, or even while at sea if necessary, as concrete will set in water without decreasing its strength. 
"It will also be seen that if a vessel of this kind should be damaged by collision or by striking a rock or an iceberg, only her outer hull could be damaged, while her freight and passengers are carried to their destination in safety. A few of the items to recommend such a vessel are:

First: A stronger and more durable sea-going vessel at less cost. vessel.

Second: Can be built in one-half the time required for a wood or steel

Third: An absolutely fireproof structure.

Fourth: A vessel practically free from vibration, greatly adding to life of machinery and comfort of passengers.

Fifth: A saving in upkeep; the hull, all outside and exposed surfaces can be of white cement, effecting a large saving in painting, etc.

Sixth: The attainment of graceful lines, and good design at no added cost, owing to the flexibility of the material while in its plastic state.

Seventh: A powerfully, strong hull with an outer surface as even and smooth as glass and proof against barnacles and corrosion.

Eighth: The arrangement of a series of watertight compartments that will make the vessel practically unsinkable."

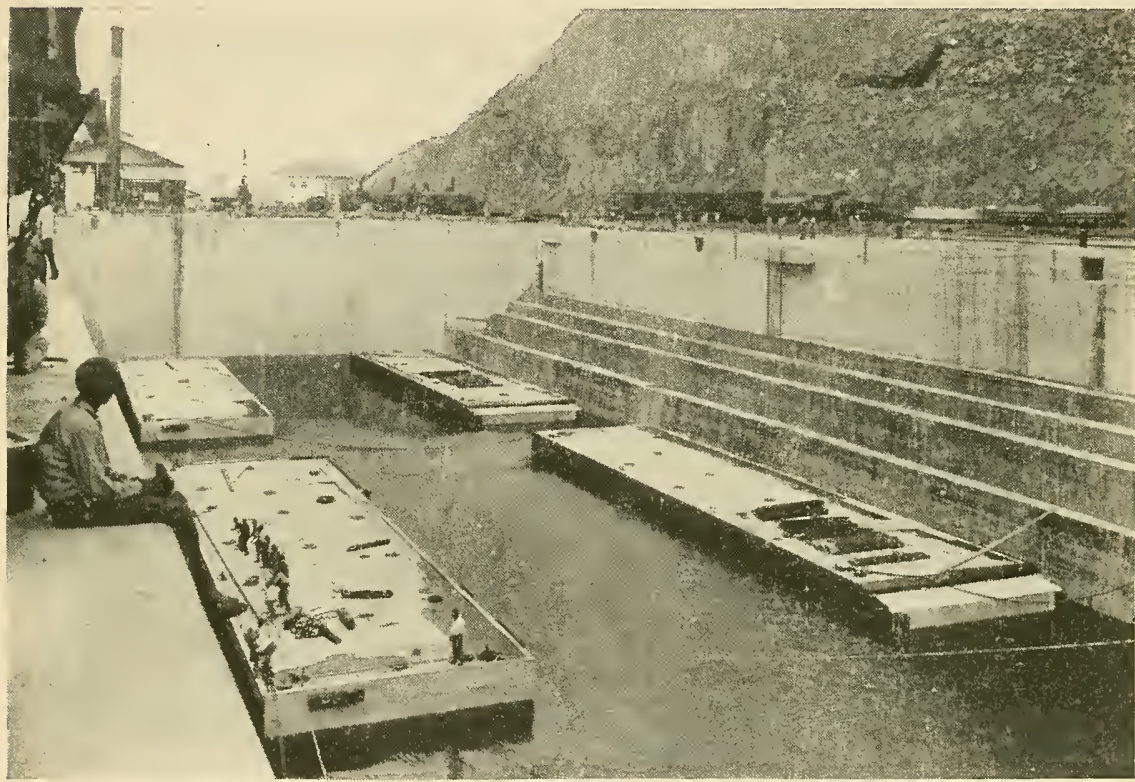

Finished Concrete Pontoons on Panama Canal, Floating in Dry Dock.

\section{Commenting on the foregoing, the Boston Evening Record says:}

"I $t$ is by the careful study and research given by the specialists, the marine engineer, the concrete engineer, the naval architect and the gun expert, each doing his own part, that the problem will be successfully solved and will bring forth the ship of such sturdy strength that on the new ship the submarine will have lost its power.

"Many are conversant with the feats of engineering accomplished with reinforced concrete; factories and manufacturing plants having great strength and practically free from vibration, bridges capable of carrying any load, are demonstrated facts, but its possibilities in modern shipbuilding are not so well known. But nearly every country in the world is making some use of reinforced concrete as applied to shipbuilding. It remains for the methods to be thoroughly worked out and perfected by specialists to give us practically an indestructible ship." 
Marine EngineERING for July, 1917, recognizes the possibilities of concrete for ships by giving space to an article by Allen Hoar, C. E., 323 r Liberty Ave., Alameda, Cal., entitled "Reinforced Concrete for Shipbuilding." Mr. Hoar shows familiarity with his subject by pointing out that the use of concrete for floating structures is not by any means a novelty and he looks to concrete as a possible solution of the shipping problem because, as he says, it is very essential that another shipbuilding material be available that has as its prime essentials, relative cheapness, abundant supply widely distributed throughout the country but particularly near our seacoasts. Mr. Hoar says in part:

"The only building material which has these qualifications, together with the necessary physical requirements, is reinforced concrete. This material presents itself as the logical one to replace steel and wood in the construction of ships, not merely as a substitute for steel or wood, but as a material superior to either of these from the standpoint of general adaptability, first cost and cost of maintenance.

Chief among the distinctive advantages of reinforced concrete is its great length of life as compared with either steel or wood. While these materials tend to decay or corrode in a very short time when subjected to the action of sea water and its animal life, concrete, if well proportioned, of first-class materials and properly applied, is absolutely impervious to the action of sea water and proof against boring animal life."

Accompanying Mr. Hoar's article are various details of a proposed design for a reinforced concrete barge and freight steamer.

In the same issue of MARINE ENGINEERING, the following editorial appears:

\section{REINFORCED CONCRETE SHIPBUILDING-A FIELD FOR PIONEERS}

The pressing need for ships and the existing congestion in American shipyards have led to a consideration of the possibility of utilizing other materials than wood and steel for shipbuilding. The most promising alternative is undoubtedly reinforced concrete, and already several prominent engineers have turned their attention to its application to the construction of ships. Various phases of the question are discussed in two articles published elsewhere in this issue.

Reinforced concrete ships are not a novelty. In San Francisco a firm of engineers is designing a ship with a length of 330 feet, a beam of 44 feet and a depth of 31 feet, with a capacity of 4,500 tons, to be built of reinforced concrete. As far back as 1898 a concrete schooner was employed for some years in the North Atlantic coasting trade. The London Times recently mentioned a small boat of reinforced concrete built by a Frenchman in 1849 which is still in service after a period of sixty-eight years. Concrete lighters have been used for the past six years on Chesapeake Bay, supplying coal and water to dredges carrying loads of sand and gravel, etc. A concrete barge has been in service on the Welland Canal since 1910 and has seen very hard usage. It has a length of $80 \mathrm{feet}$, a beam of $24 \mathrm{feet}$ and a depth of 7 feet. The walls of the barge, which were constructed between forms, are $21 / 2$ inches thick, reinforced with steel rods. The barge has been used for carrying loads of stone, etc., with conspicuous success. Since 1910 reinforced concrete barges have been built for use on various sections of the Panama Canal, and their experience has enabled the engineers to develop a very efficient type of vessel. Recently concrete pontoons were constructed for service as landing stages for boats up to 65 feet in length. These pontoons have a length of 120 feet, a beam of 28 feet and a depth of 8 feet. They are very thoroughly reinforced.

Vessels which are much more like ships than barges have been built of reinforced concrete in Norway. A report from the American Consul-General at Christiania describes a plant at Moss, Norway, where vessels of 3,000 tons displacement are being constructed. At this place a concrete lighter having a displacement of 3,000 tons, which 
C ONCRETESHIPS

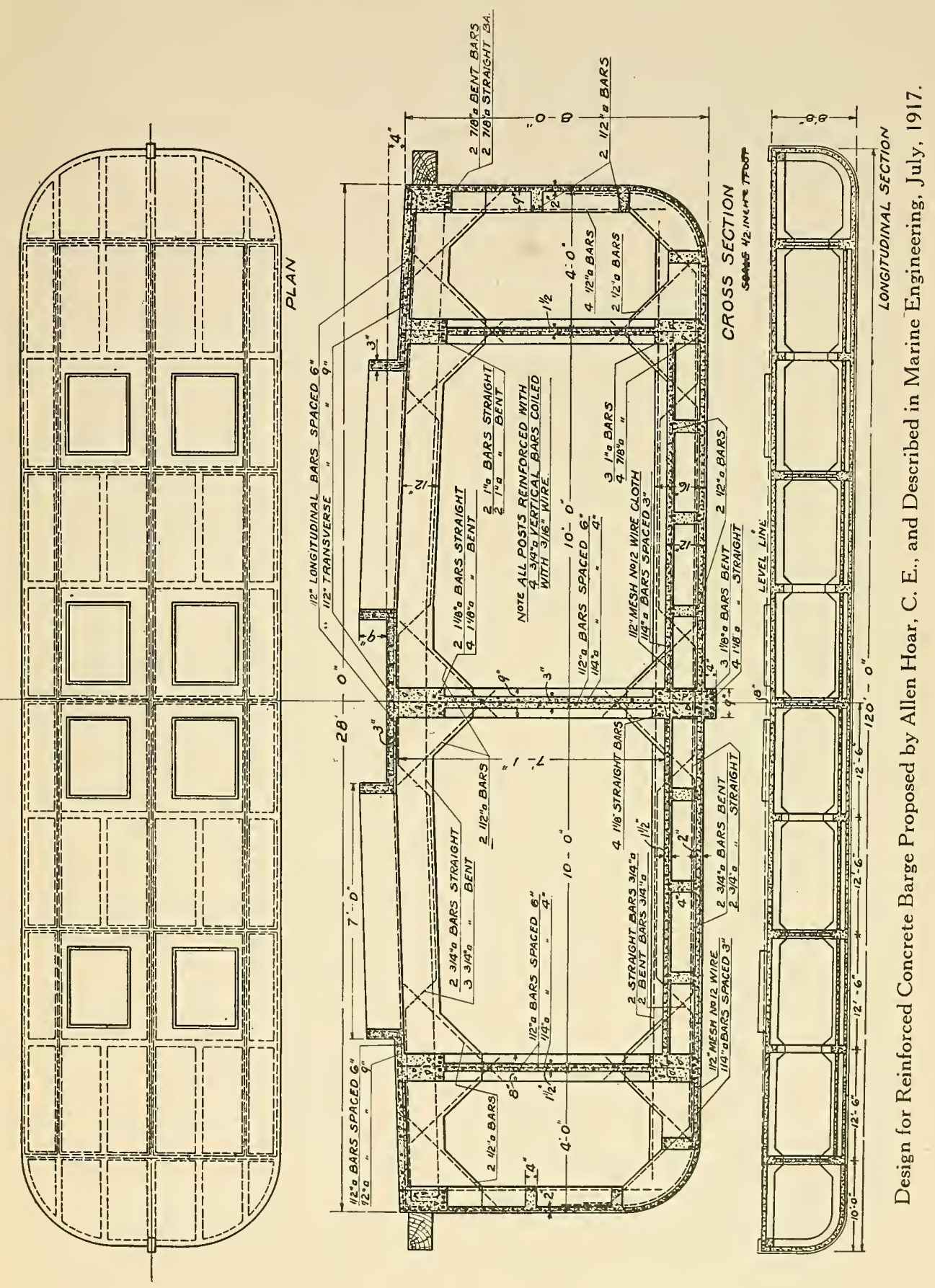




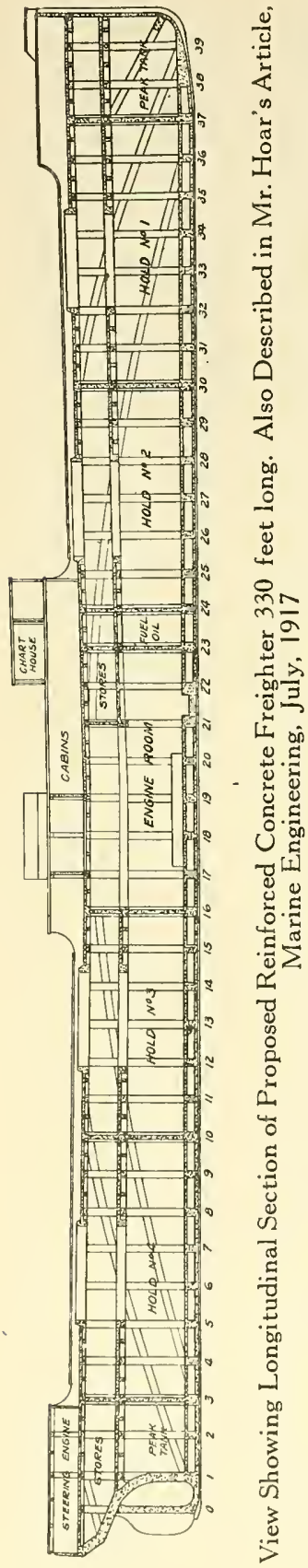

is being built for a mining company at Sydvaranger for the oversea export of iron ore and the import of coal, will be completed before the end of the current year. Two other lighters are now on the stocks and a large slip for a 4,000-ton craft is nearly completed. More than 200 men are now working in the new yards and five lighters have been contracted for in addition to the one completed and the two on the slips.

In view of such examples, proving the usefulness of concrete vessels of this character, the possibilities of constructing seagoing barges or other smaller craft suitable for inland waterway traffic should be carefully investigated in the United States, for the substitution of such vessels for existing tonnage would in a short time release for other purposes many ships now used in domestic service. The presence of the necessary materials for building concrete vessels at so many convenient locations, and the ease and rapidity with which they can be built by unskilled labor, would seemingly make it possible to provide a large tonnage of such craft in a relatively short time.

Progress in the development of seagoing concrete steamships must necessarily be slow at first, as real information is lacking as to how such vessels will stand up under shocks. Seafaring men who have handled vessels in North Atlantic winter storms or in West Indian hurricanes realize that such information cannot be gained from laboratory experiments. The behavior of actual concrete ships under power in a seaway must be studied.

The Engineering Supplement of the London Times, May 25, igi7, after citing some examples of the use of concrete in boats and barges, discusses the possibility of future developments as follows

"It is evident from the examples cited that reinforced concrete has earned a definite claim to be regarded as a real shipbuilding material, particularly for vessels of moderate size. Whether it will prove equally suitable for the construction of large steamships, including ocean liners and warships, is a question that can be answered only by the results of future experience. In the meantime the material possesses obvious advantages for the building of many useful types of craft. Among its recommendations are simplicity and rapidity of construction, the readiness with which repairs can be executed, high resistance to strain and shock, incombustibility and fire-resistance, relatively low cost, and the virtual elimination of maintenance charges. Experience appears to show that the skin-resistance of a reinforced concrete vessel to passage through water is slight, owing to the smoothness of the surface and the absence of joints, and the ease with which scraping can be effected.

". reinforced concrete lends itself to the most modern developments in shipbuilding design, and although the skin of the hull must necessarily be thicker than when steel plates are used, it need scarcely be thicker than would be the case if timber were employed. Assuming 3 inches to be the thickness adopted the weight per square foot would be less than that of steel I inch thick. Therefore the question of deadweight does not appear to constitute a very serious objection, especially in view of the fact that the weight of the hull of a vessel is small in comparison with the weight of equipment, fittings, and cargo." 
Even if large ocean-going concrete ships are not at once made a reality, there is no end of opportunity for constructing barges and lighters for lake, river, and coastwise service. Any considerable number of such carriers would at once release for ocean-going use, ships now in Great Lakes or coastwise traffic.

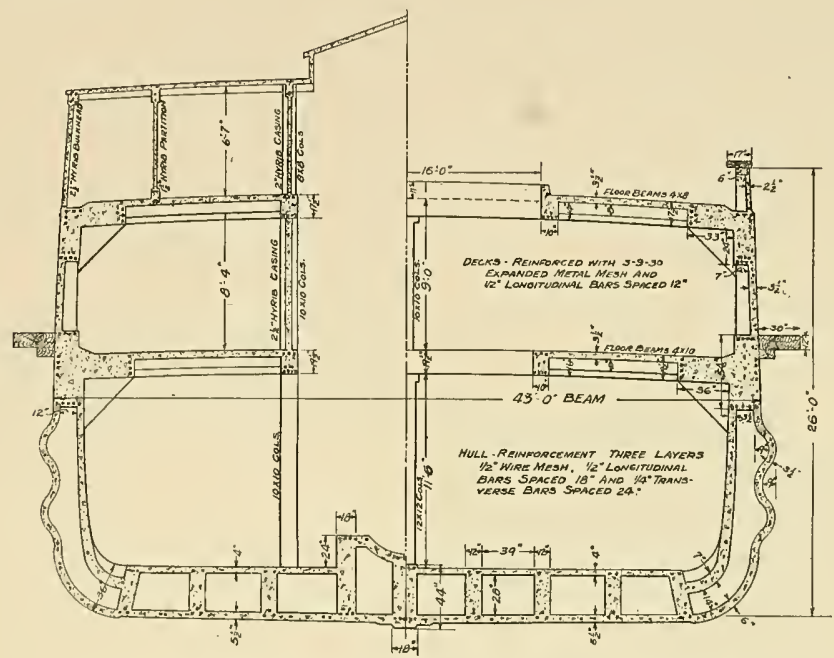

Transverse Section of Reinforced Concrete Freighter. Marine Engineering, July, 1917.

This thought has been well expressed by the editor of the GREAT LAKES WEEKLY, a paper devoted to shipping interests on the Great Lakes, published in Milwaukee, who says:

"There is no reason why there should not be a great field for these concrete barges and ships on the Great Lakes. Every kind of an old trap and almost every bottom that floats is being used and I believe that if the shipping men, especially those that are in the class for smaller tonnage, could be educated up to this new kind of shipbuilding there soon would be something doing in the marine field. They are having considerable trouble on Lake Erie and Lake Ontario to get sufficient tonnage especially in the coal field between American and Canadian ports, and barges or ships of this kind of construction could be utilized in that field."

Concrete and Constructional Engineering, published in London, says, in its April, I917, issue, that arrangements are being made for the construction of concrete vessels in France and that "a company has been formed in Paris to be known as La Material Flottant, to build seagoing lighters, also docks and other floating or fixed constructions of concrete."

The same magazine reports the construction of a reinforced concrete motor cruiser last year by several members of the Sabin Hill Yacht Club, Dorchester, Mass. The craft is $4 \mathrm{I}$ feet over all with a beam of 8 feet. The following description is taken from the magazine: 
"The framing of the boat is of angle steel, and a 10-inch steel H-beam forms the keel. Galvanized expanded steel was attached to the framing to hold the concrete, which tapers from $11 / 2$ inches thick at the keel to $7 / 8$ inch at the gunwhale. At each side at the water line, as may be seen in our illustration, is a sponson, which increases the beam to 11 feet, and gives the vessel great buoyancy in a seaway, making her, in fact, practically unsinkable. Power for propulsion is derived from a $25 \mathrm{~b}$. h. p. to $30 \mathrm{~b}$. h. p. four-cylinder Buffalo engine, which gives a speed of $71 / 2 \mathrm{knots}$. Either petrol or paraffine may be used for running, and the tanks hold 1,000 gallons, or enough for a cruise of, say, 40 days. Apparatus for developing moving picture films is fitted up in the after cabin, while in the main cabin forward special bunks with deep sides for bad weather are provided."

\section{Examples of Concrete Ship Construction}

\section{CONCRETE BOATS ORIGINATED IN FRANCE}

Perhaps few persons are aware of the fact that the first use of what would today be called reinforced concrete was in boat building. In 1849 , there was built and patented by M. Lambot, of Carces, France, a rowboat

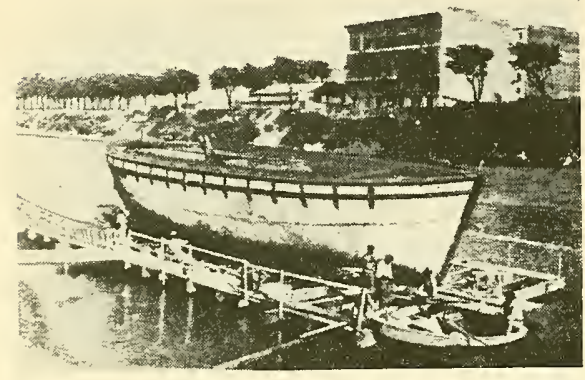

Reinforced Concrete Boat "Liguria," Built by Carlo Gabellini, Rome, I taly. which in reality was of reinforced concrete. This structure, if it may so be called, marked the starting point of the history not only of concrete boat building but of reinforced concrete. The boat was exhibited by its maker and patentee at a world's fair held in Paris in 1855. It is said that it is still in service. (See illustration page 3.)

The work of M. Lambot in this early departure of boat building was investigated by the French Government in 1850 but, as is often the case, further development was left to private individuals. From this small beginning, reinforced concrete construction has developed to the point where today it enters into the building of practically every known type of structure.

\section{CONCRETE SHIPS IN NORWAY AND ITALY}

Records seem to show that Norway and Italy have applied concrete to ship construction more extensively than has been done in any other country. A Norwegian vessel of 3,000 tons is now in service. This was built by a company at Moss, Norway. The ribs of this vessel are steel. Its hull is of reinforced concrete. Numerous small barges, scows and lighters also have been

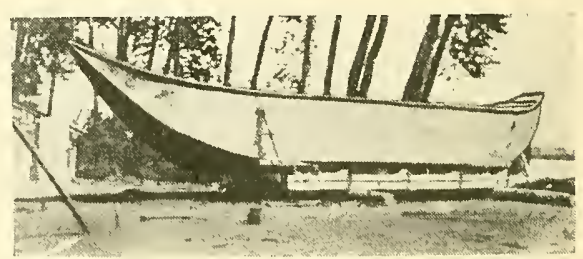

Bridge Pontoon of Reinforced Concrete. Another Example of Gabellini's Construction. 
successfully built and are operated with such economy that many others are under construction.

A recent advertisement in the Norwegian Shipping Gazette, translated, reads:

“Fougner's Steel Concrete Shipbuilding Company. Lighters of steel concrete 100 tons dead weight can be delivered in from 6 to 8 weeks. Seaworthy motor ships about 200 tons dead weight can be delivered in from 3 to 4 months. Larger lighters and motor

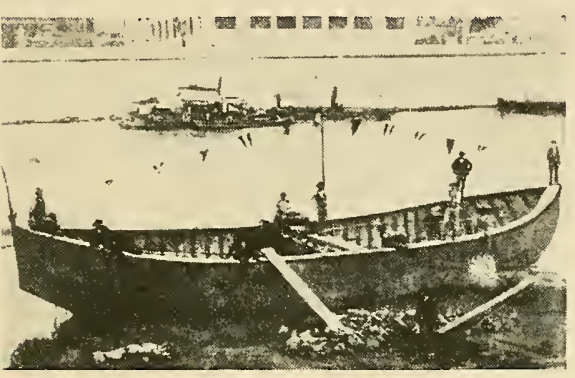

Reinforced Concrete Boat “Ettore," Built by Carlo Gabellini. ships up to 3,000 to 4,000 tons dead weight for delivery the first half of next year. Building of floating dry docks can be contracted for the latter half of 1917."

In a late report the American Consul-General at Christiania describes the plant of the shipbuilding concern at Moss, Norway, and refers to the construction of $3,000-$ ton concrete boats at this plant. The following quoted from the report indicates the extent of the work under way at that time:

"The inventor of this new style of vessel is said to be M. Nicolai Fougner, an engineer, who claims to be able to construct a ship of any size demanded. He is now building a lighter for a mining company at Sydvaranger for the oversea export of iron ore and the import of coal. The vessel, having a displacement of 3,000 tons, is to be ready before the end of the current year, 1917. It is stated that these concrete ships can be sailed or engined like other vessels, and experts consider that a new epoch in shipbuilding has arrived.

"The ship, which arrived in Christiania last month, resembles a large barge, and is constructed entirely of concrete with the exception of the ribs, which are of steel. This new method of constructing ships has attracted much attention. The Swedish Minister of Marine, M. Brostrom, one of Sweden's largest shipowners, immediately ordered a lighter of some thousand tons displacement, and he was present when the craft was launched at Moss. He was accompanied by four experts, all of whom expressed much satisfaction at the result.

"Two other lighters are now on the stocks, and a large slip for a 4,000-ton craft is nearly completed. More than 200 men are now working in the new yards, and five lighters have been contracted for in addition to the one completed and the two on the slips."

Since the foregoing report was written, the following news item has appeared in MOTORSHIP (Seattle) for June, 1917:

\section{3,000-TON DIESEL MOTORSHIP OF FERRO-CONCRETE}

There is due for delivery in July, the first large motorship of ferro-concrete construction, which now is on order for the Sydvaranger Mine Company of Norway, and will be used for carrying

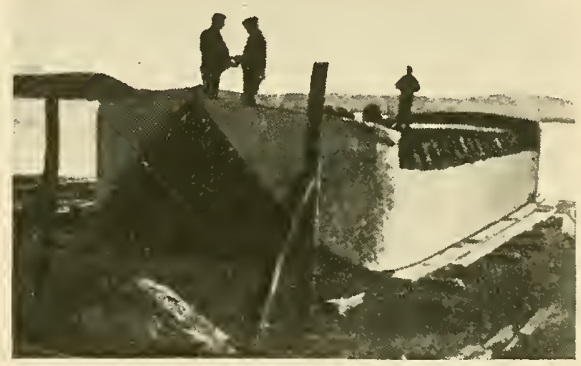

Reinforced Concrete Pontoon Under Construction at Carlo Gabellini's Shipyard. 
iron-ore across the North Sea. She is of 3,000 tons and is being equipped with two direct-reversible Polar-Diesel engines each of 300 b. h. p. Her builders are the Fougner's Staalbeton Skilsbygnings Co., of Moss, Norway, who will build semi-concrete hulls up to 5,000 tons per ship.

At the time this booklet was written (July, 1917), Jens Hauland, Vice-President and General Manager of a concrete products plant at Porsgrund, Norway, was in the United States exhibiting a 9-foot model of a boat built according to plans that the company of Mr. Hauland is following in constructing concrete vessels of 200 tons capacity. One such vessel was nearing completion was to have been launched early in August. The g-foot model spoken of was turned over to the United States Bureau of Standards to enable it to study the methods of construction. Mr. Hauland says that companies have been formed in Bergen, Norway, and Buenos Aires, South America, to build concrete vessels after the plans his company is using. Elsewhere in this booklet there is reproduced a photograph of the 9-foot model spoken of, also a drawing showing some of the features of this construction.

An interesting feature of the method used at Mr. Hauland's plant at Porsgrund, Norway, is that the vessel is built bottom up, an internal mold being used which is made in units that can easily be taken apart and reassembled. The vessel is launched in the same position in which it is built - bottom up - and by special arrangement of interior compartments that admit a small amount of water, the vessel is self-righting when launched. The general structure of the vessel is a series of transverse ribs with a thin shell and because of the fact that it is cast bottom side up, it is easier to control the density of the concrete along the bottom and lower side of the hull, consequently thinner sections can be used than might otherwise be possible.

\section{CONCRETE SHIPS IN ROME}

In 1899 , Carlo Gabellini, of Rome, Italy, began the construction of concrete scows and barges. His process had been so developed by 1905 that a I 50-ton barge was constructed for the city of Civita Vecchia. The following year another barge was built for the military harbor at Spezzia, for use of the Italian navy. This latter barge before acceptance was put to the severe test of being driven against some piling and afterward being rammed by a steel towboat. Results of these tests were so satisfactory that construction of similar boats or barges followed.

In 1909, a special representative of BETON U. EISEN, a Berlin publication, visited the works of Gabellini and made a detailed report of the methods by which these barges were constructed. As these differ considerably from methods which up to this time had been used elsewhere, they deserve description.

\section{Page Fourteen}



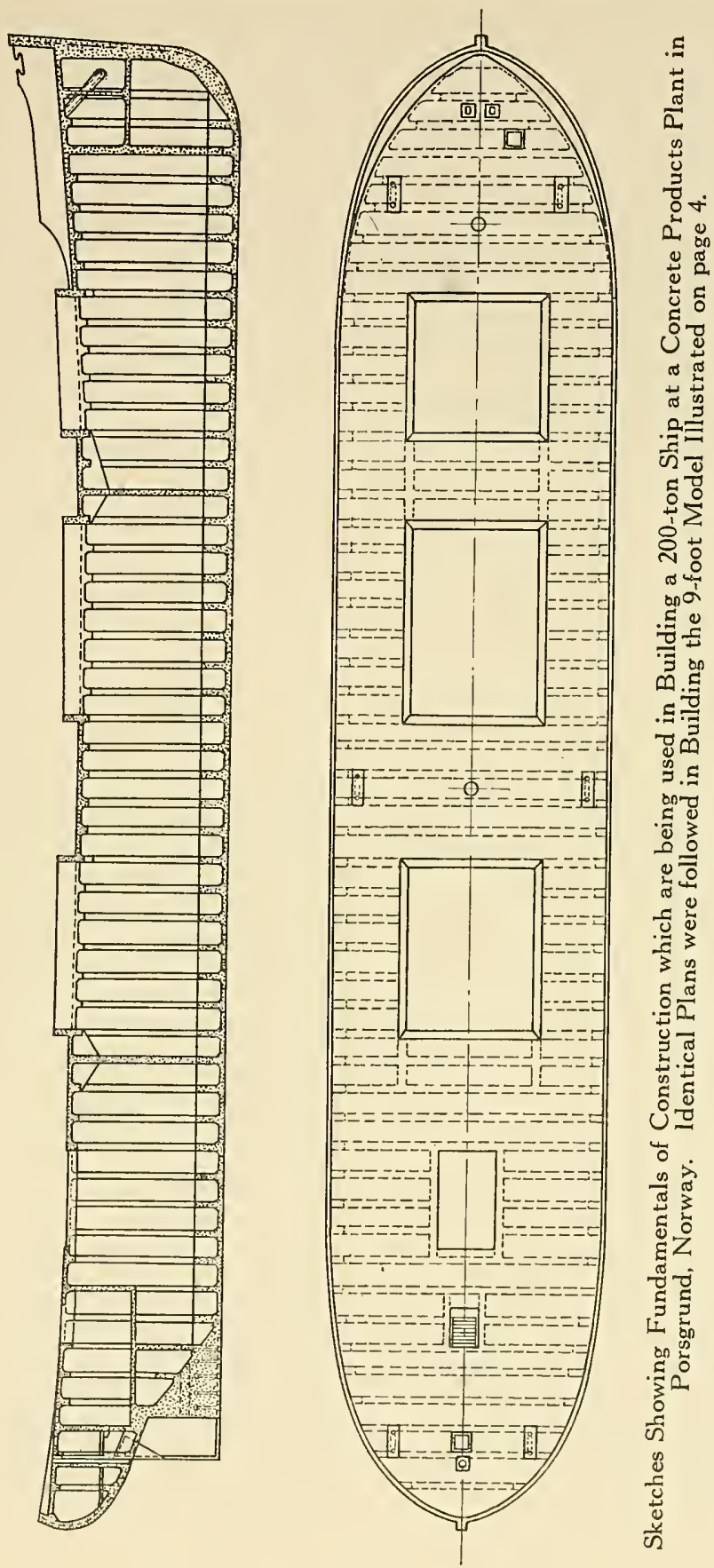


\section{GABELLINI METHOD OF CONSTRUCTION}

The first step in "laying down" these vessels consists of placing reinforcement for the keel and ribs. This reinforcement, which usually consists of round steel rods, is then covered on the outside with $1 / 4$-inch wire mesh, to which a I-inch coat of cement

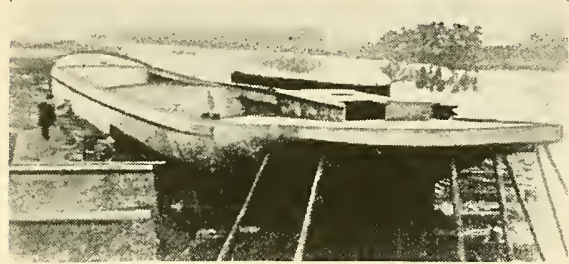

Concrete Barge Built at Frankfort-on-theMain. mortar is applied by hand. Next, a somewhat thinner coat of mortar is placed on the inside, following which forms for the ribs and keel are put in place and concrete deposited for these parts of the vessel. These ribs run both longitudinally and transversely so that a checkerboard arrangement results, the pockets being 10 inches deep and the ribs about 2 inches wide. Over these ribs $1 / 8$-inch wire mesh is placed and a thin mortar covering plastered on. Finally a third and coarser wire mesh is pressed into the soft mortar and the entire surface troweled over. This completes the hull. Bulkheads are next concreted and the boat finished with a wooden sheer strake and gunwale.

At the time this inspection of the Gabellini yards was made, there were in process of construction several railroad car ferry floats large enough to carry six coaches. These floats were intended for use at the railroad ferry in Venice. They were designed to take rails 154 feet long.

\section{CONCRETE SHIPS \\ IN HOLLAND}

The first concrete boat in Holland was built in 1887 by the Fabrieck van Cement-Ijzer Werken. This concern first built barges up to I I tons capacity, which proved so successful that plans were elaborated resulting in the building of barges 64 feet long and 14 feet beam, of 55 tons capacity. Briefly, the system of construction

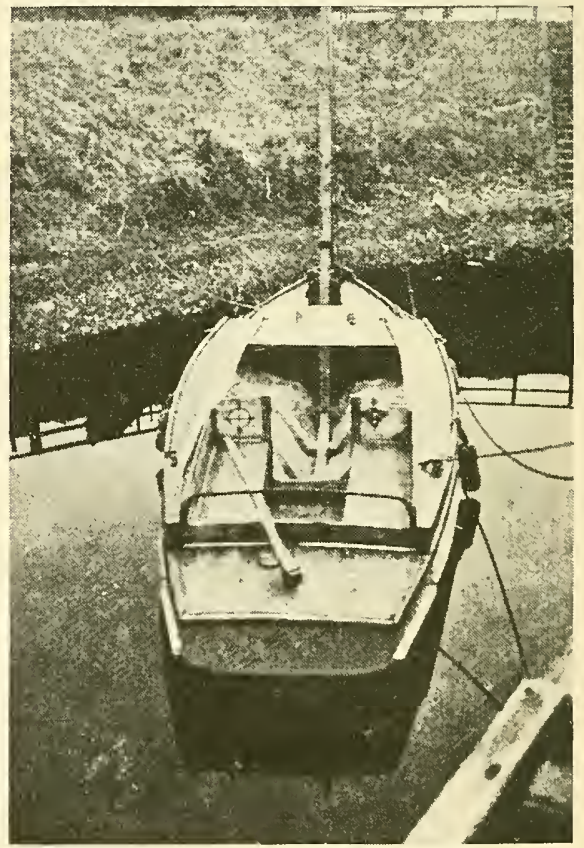

Reinforced Concrete Sailboat Built by Johannes Lescher. 
consisted of building longitudinal and transverse bulkheads spaced approximately on 6-foot centers, thus providing a cellular construction which made the ship practically unsinkable.

Of interest also is some work done by R. Last \& Sons, a concrete firm in Holland, who built a motorboat in which a framework of steel ribs and longitudinal rods, to which wire mesh was attached, was covered with a coat of mortar. This finished shell was but $1 / 2$ inch thick. The boat had room for six or eight people and was propelled by a motor which drove it at mod-

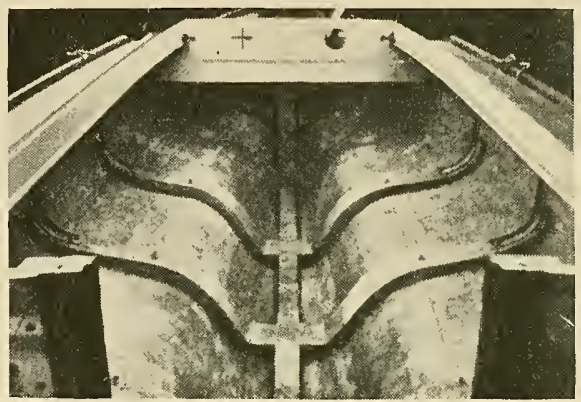

Interior View of Lescher's Concrete Sailboat. erate speed. However, the boat was intended only for pleasure purposes.

\section{GERMAN CONCRETE BOATS}

Following precedent established by the Dutch, German shipbuilders constructed, in 1009, at Frankfort-on-the-Main, a concrete freighter of

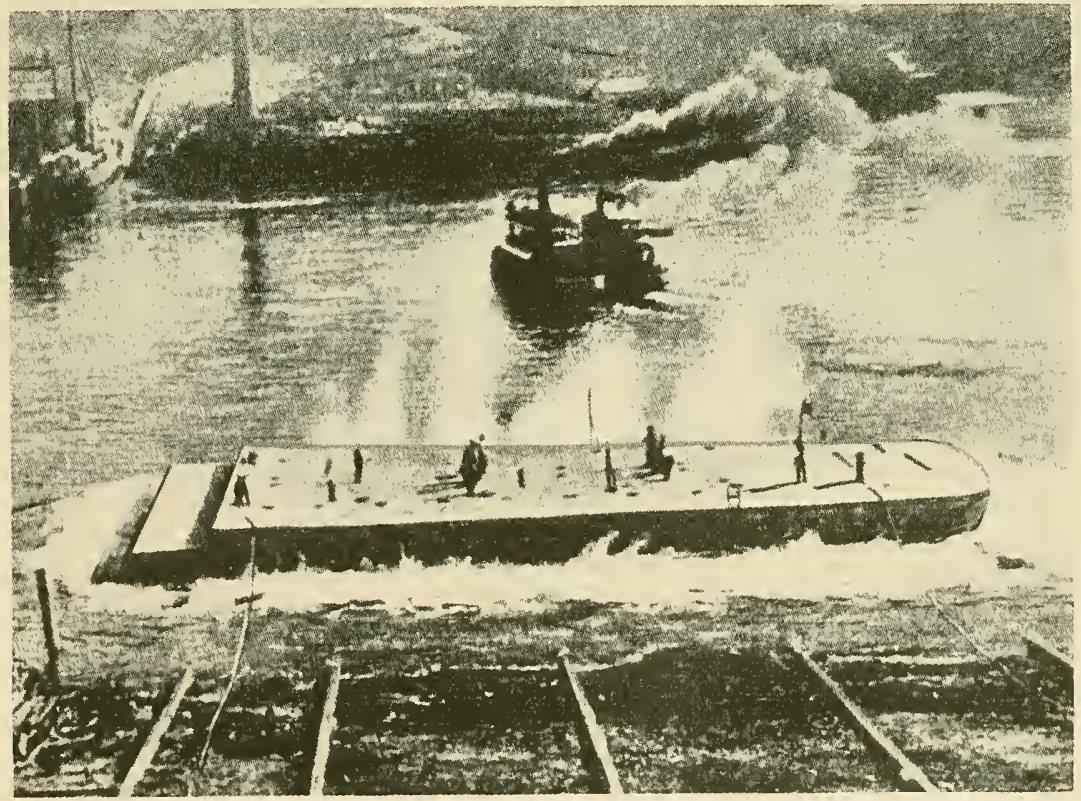

Launching Concrete Pontoon Built by the Sydney Harbor Trust, for Use in Circular Quay, Sydney, N. S. W., in 1914. 


\section{CONCRETE SH I P S}
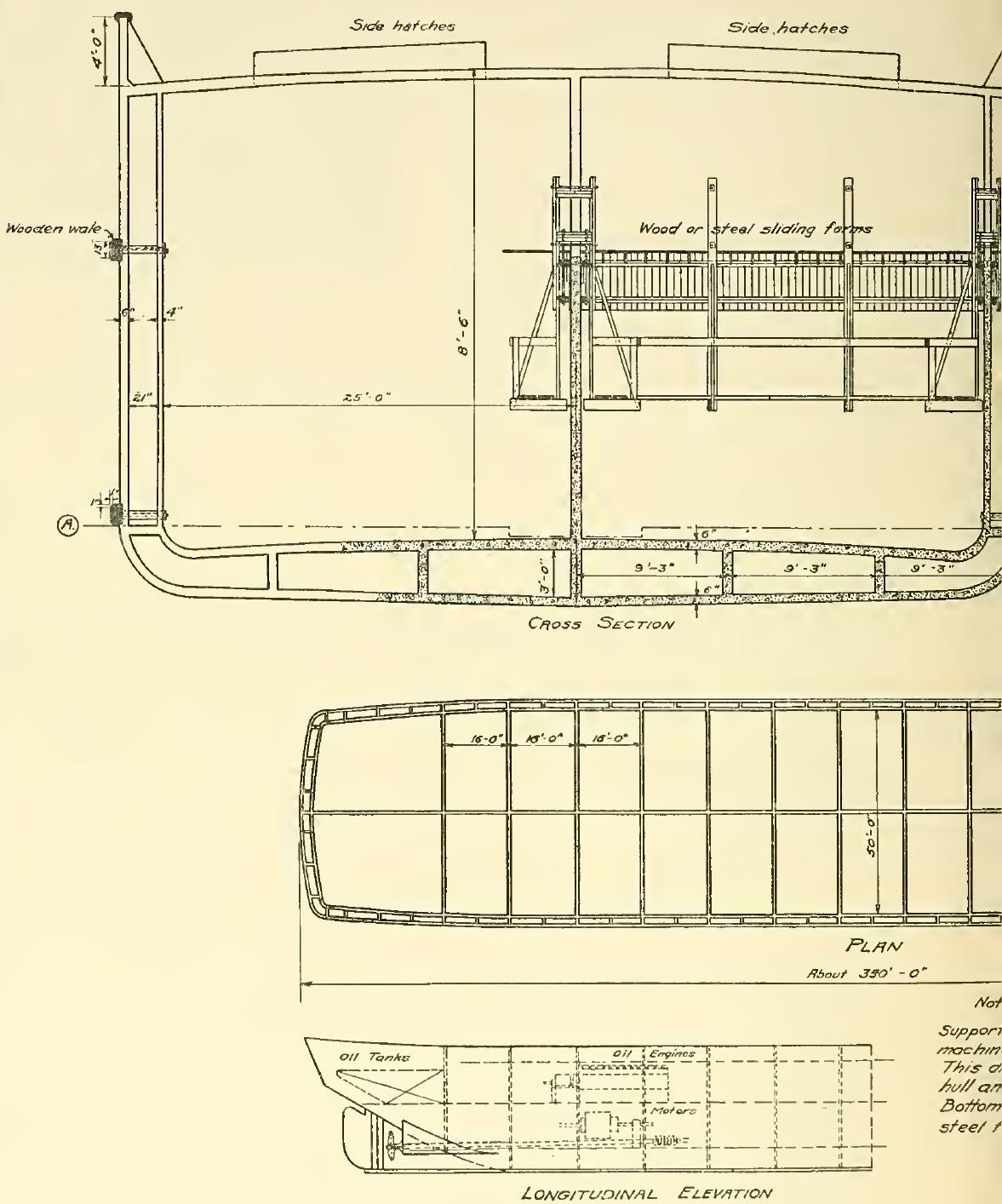

Suppor? mochin This of hull an Bottom steel $t$ 


\section{O N C R E T E S H I P S}

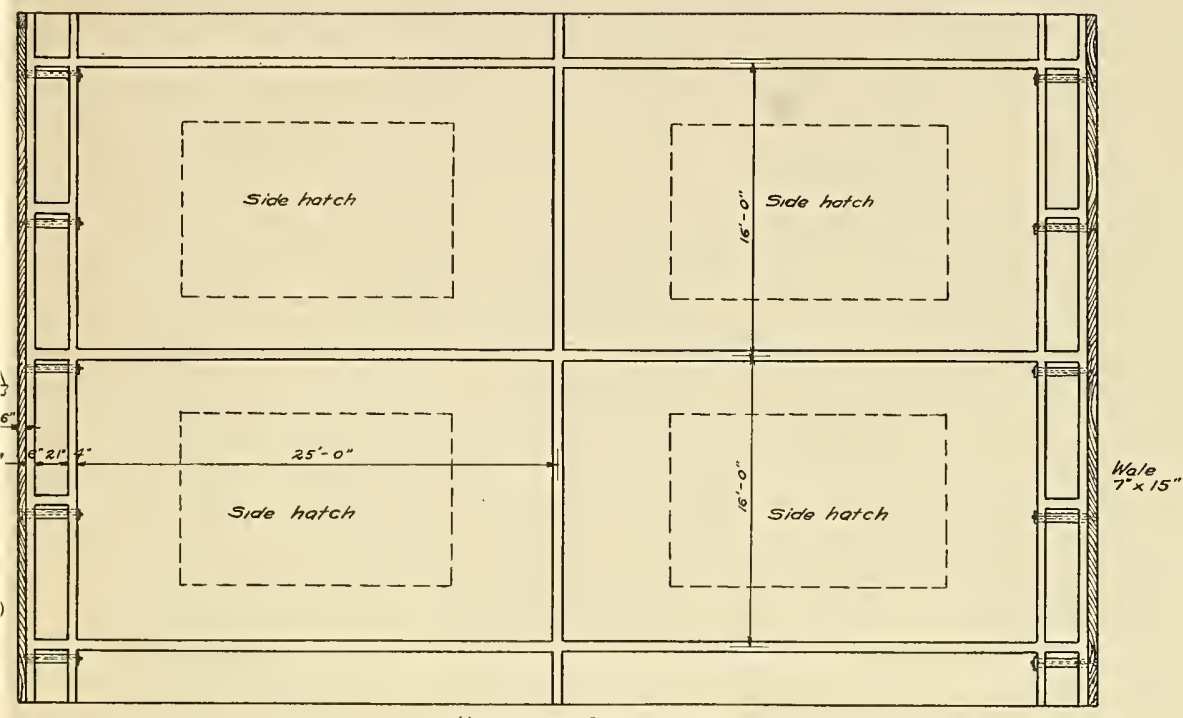

HORIZONTAL SECTION OF HOLO

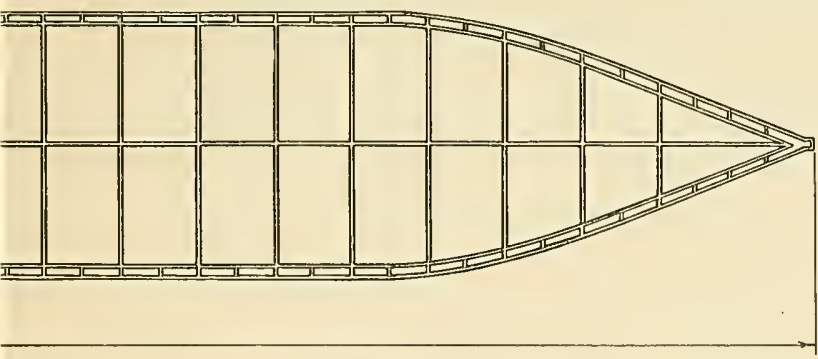

inks, engines, motors, shorting and horsting

thly struct steel acc to special design.

is anly to illustrate general design of the iod of ropid construction of same

biloe constructed by collapsible wood or 0 to line (A.) - (A.)

ed by E. Lee Heidenreich, Kansas City, Mo.

Ernest Simanson.-Del

Scales:-

(Potents Applied Fon)

SHETCH OF

REINFORCED CONCRETE

TRANSPORTS

- Proposed By -

E.Lee Heidenreich, C.E., ME

May 21,19/7. Konsos Cify,M. US.A. 



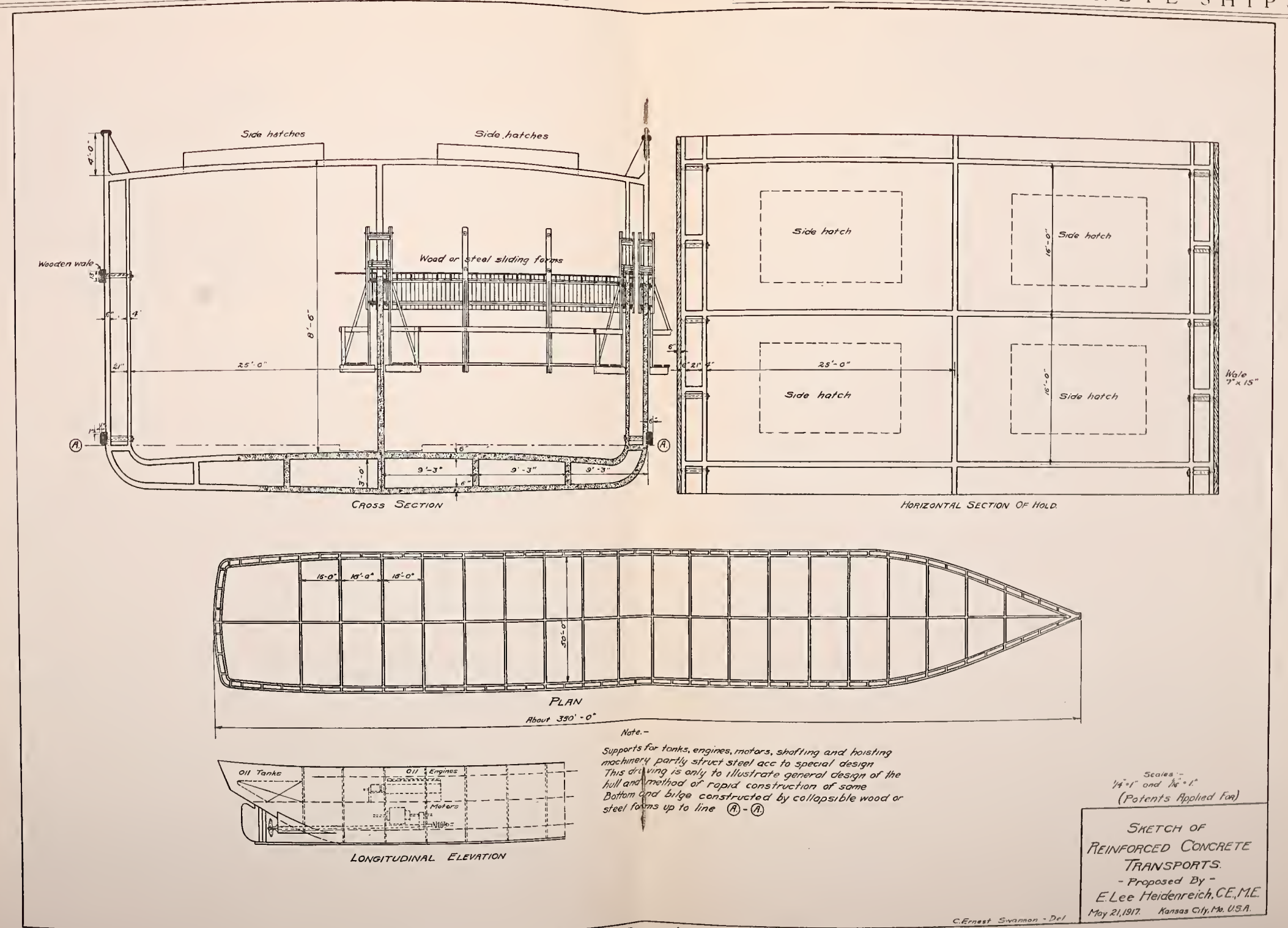


220 tons. This boat was built by the Allgemeine Verbundbaugesellschaft, simple forms being set up and concrete placed between them. The result was a boat, the main hull of which had parallel sides, yet elsewhere a shape with fairly good lines so that the water resistance was decreased below that of a rectangular barge. Rectangular compartments forming watertight bulkheads similar to those used by the Dutch were a feature of construction. A small after cabin completed the vessel.

In I912, Herr Johannes Lescher, of Dresden, conceived the idea of building a concrete sailboat. His design embodied the latest principles

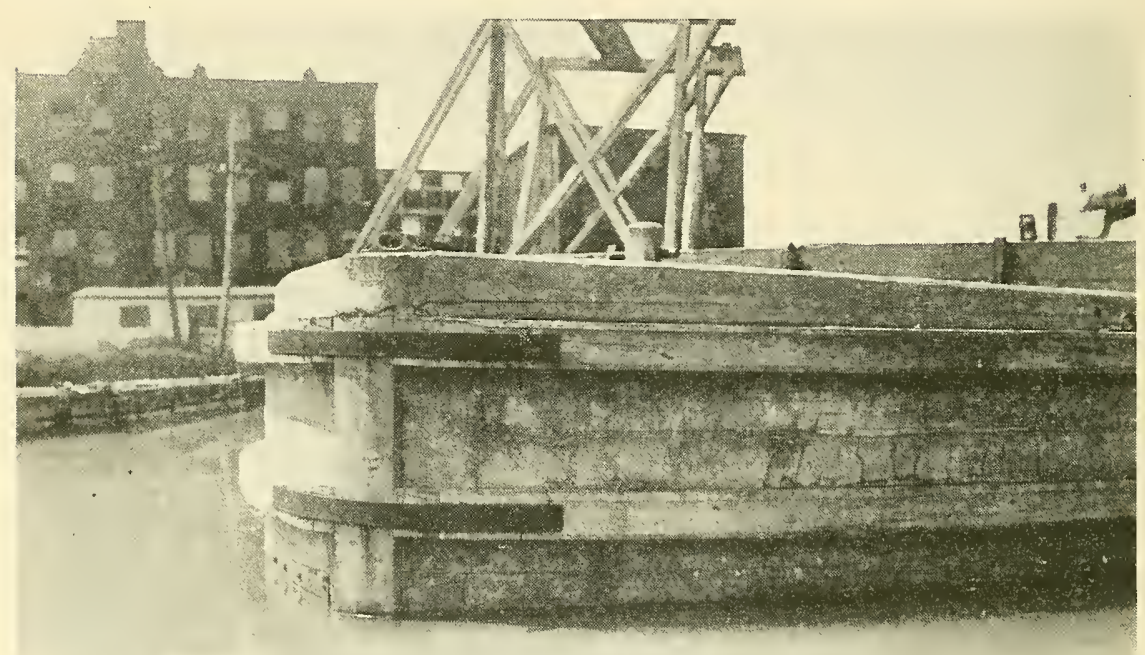

Front View of the Barge "Pioneer" on the Welland Canal, as it now appears. The slight crack where the coping joins the main point of the concrete on the prow is explained by $\mathrm{J}$. L. Weller, Engineer in Charge, as due to the fact that this coping was put on as an afterthought and the bond between the old and new concrete was not properly provided for. The cracks that can be noticed on the side came from a severe collision which the barge withstood some time ago. When the barge is loaded, these cracks are below water line, but have never resulted in leakage.

of sailing vessel construction as to shape of hull and method of computing construction. Designs were worked out for three conditions - floating in disturbed water; to withstand lifting with a single crane; and to rest on its keel on dry land, filled with water. This boat was launched in April, 1912, and in spite of frequent groundings, gave excellent service for nine months following its completion. Its present condition, for obvious reasons, cannot be determined. 


\section{NEW SOUTH WALES USES CONCRETE PONTOON}

In 1914, the Sydney Harbor Trust decided to build a pontoon for use in Circular Quay, Sydney, N. S. W. After investigating various available
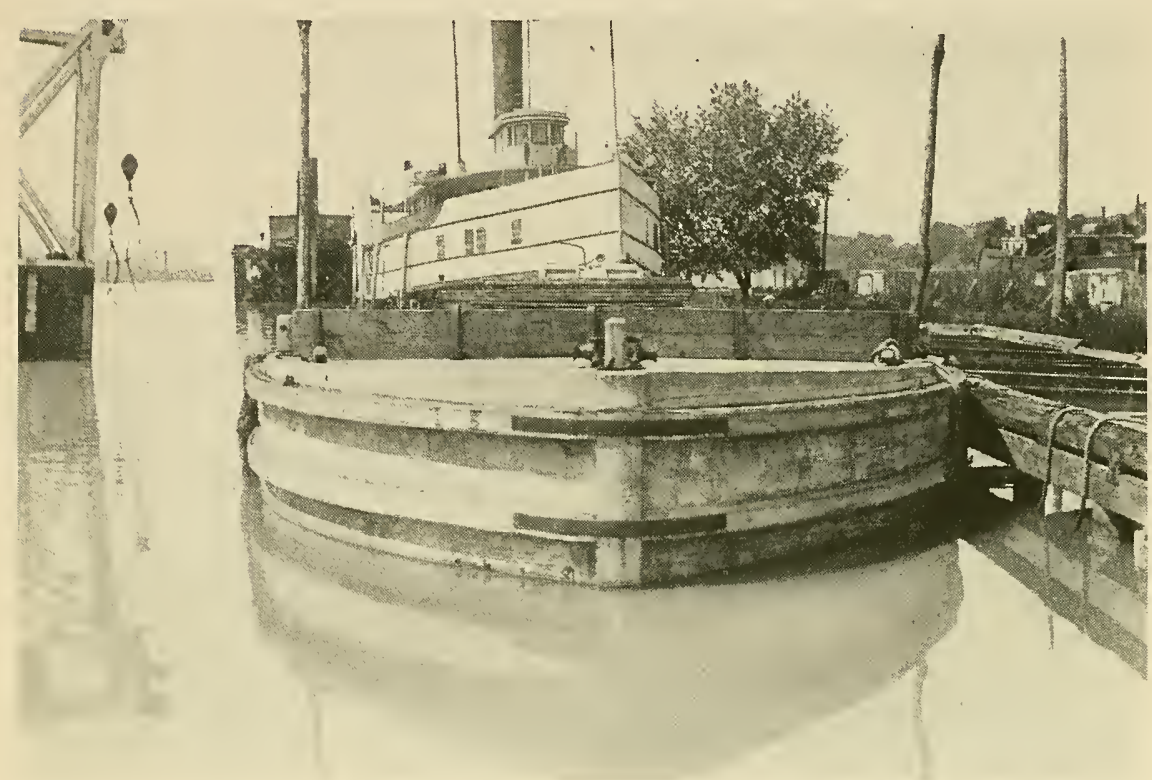

This Front View of the Barge "Pioneer" in use on the Welland Canal Shows the 6 by 8 -inch Oak Wales Which Serve as Fenders.

methods of construction, decision was reached to use reinforced concrete as it seemed likely this material would eventually prove cheapest because of durability and low maintenance. This pontoon is 110 feet long, 53 feet 3 inches wide at the bow, 67 feet 7 inches at the stern, has a draft of 7 feet 9 inches and deck area of 6,000 square feet. The total displacement is 783 tons. 342 cubic yards of concrete and 43 "tons of reinforcing steel were used in its construction. The bottom of this barge is 5 inches thick. Bulkheads 4 inches thick divide the whole into 44 compartments, which support an 8 -inch concrete floor, or deck.

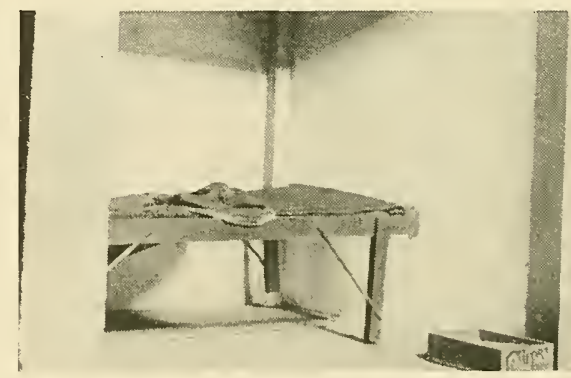

View of the interior of the barge "Pioneer" taken after six years' use of this barge on the Welland Canal. The barge is still in service. 


\section{CONCRETE BARGES ON THE MANCHESTER SHIP CANAL}

A 100 by 28 -foot concrete barge built to carry sludge pumps, boilers and fuel for use on the Manchester Ship Canal, England, has been found extremely economical. This was built by the Yorkshire Hennebique Contracting Co., Ltd., Leeds, England. Its cost was low, and maintenance on it has been found less than on similar barges of other types of construction. Experience has proved that no interruption in its service is necessary, as such repairs as may be needed can be made without dry-docking. Bottom and walls of this barge are 3 inches thick except under the boiler room and coal bunkers, where they are 4 inches thick.

\section{CONCRETE BARGE ON WELLAND CANAL PUT TO SEVERE TESTS}

That concrete barges can successfully withstand rough usage is well illustrated by experience with a concrete barge in use on the Welland Canal, Canada. This was launched November 9, 1910, since which time it has been used principally to carry stone. The barge measures 80 by 24 and has a draft of 7 feet. At times whole carloads of stone from dump cars were dropped upon its deck from a 12 -foot trestle, without injury. An article in Engineering News, New York, of January 4, i915, called attention to the satisfactory service which this boat had given for four years. This period was sufficient to reveal defects, had there been any. The fact that no serious ones were disclosed should prove beyond question that concrete barges are a success.

\section{CONCRETE BARGES ON THE PANAMA CANAL}

Concrete barges built on the Panama Canal in 1911 proved good examples of what service such barges could render under adverse conditions. In this case concrete was selected as the construction material because no skilled labor for steel or wood ship construction was available, nor could steel plates nor suitable seasoned timber be obtained within the time required. Concreting materials were at hand in large quantity and the expediency of using concrete suggested itself as a happy solution of the problem.

The design of these barges called for a structure 64 feet long by ${ }_{24}$ feet wide, with a depth ranging from 5 feet 4 inches to 5 feet 8 inches. Walls were made $2 \frac{1}{2}$ inches thick because the barges were intended for use merely as floats to carry suction pumps and engines. The only bracing of the hull consisted of two 3 -inch bulkheads extending from bow to stern.

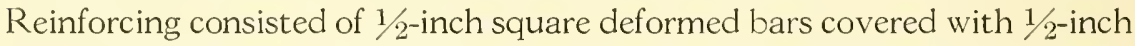
No. 12 wire mesh. Reinforcing was suspended in place from wooden beams and properly located by constructing a wooden platform placed 
C O N C R E T E S H I P S
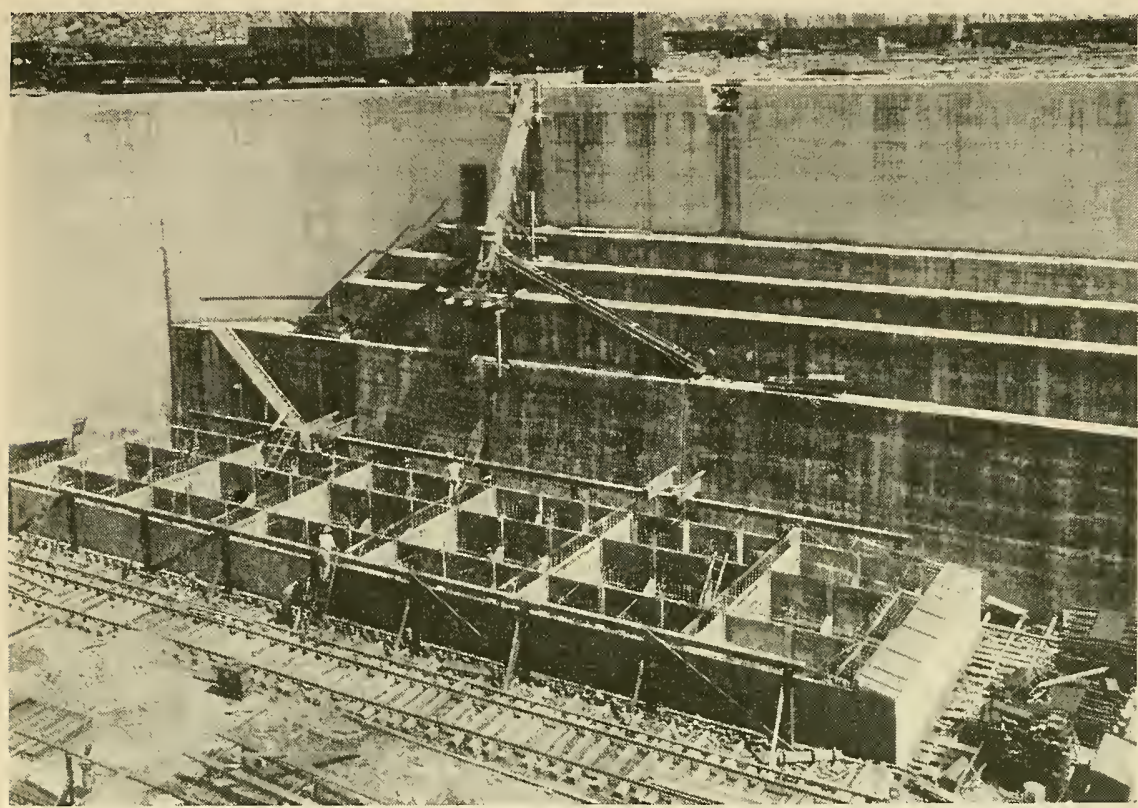

Construction View of Concrete Pontoon Built for use as a Landing Stage on the Panama Canal. This illustration shows one of the Pontoons Immediately After Forms had been Removed.

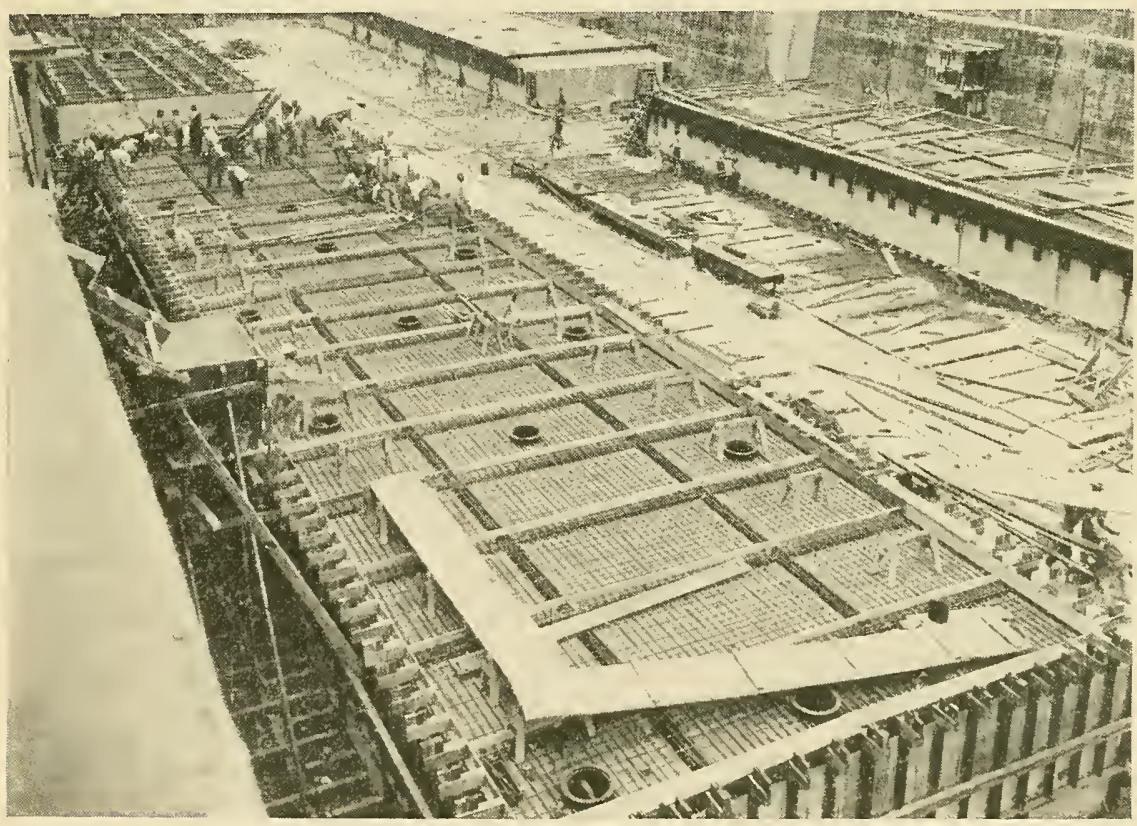

General View of Reinforcement in Place for Constructing Deck of Concrete Pontoons in Use on Panama Canal. 
at an elevation corresponding to the bottom of the barges. Bars were placed on 9-inch centers lengthwise, and I 2-inch centers crosswise, after which the platform was removed and the network of reinforcing covered with wire mesh. A $1 / 2$-inch coat of cement mortar was then applied to the wire mesh. Ten running feet of the barge length for its entire width was built up at one time.

Success with concrete barges constructed on the Panama Canal in 1911 led to the selection of this material for other barges or pontoons for use as

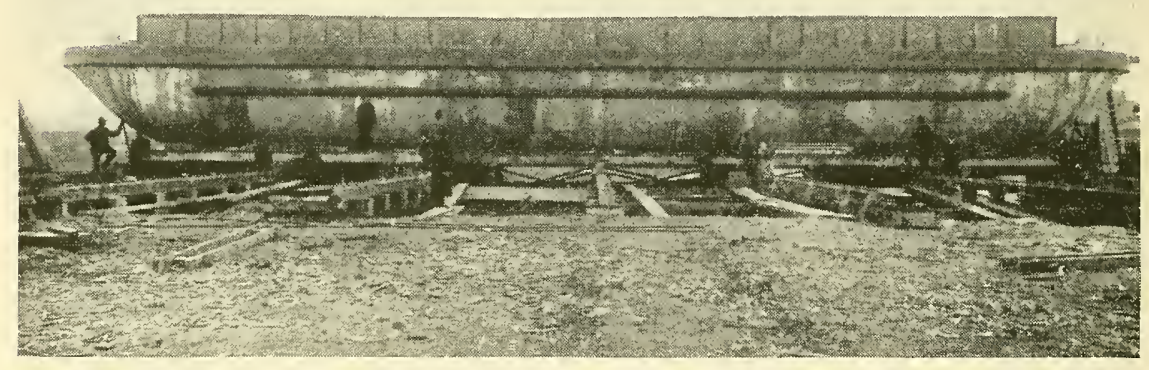

Side View of one of the 500-ton Barges used by the Arundel Sand \& Gravel Co., and the Raymond Concrete Pile Co., on Chesapeake Bay. Designed and Built by Oscar F. Lackey, while Harbor Engineer, Baltimore, Md. This picture shows the Barge on the Ways.

landing stages for boats up to 65 feet long. These later barges or pontoons are 120 feet long by 28 feet wide and 8 feet deep. Work on two of these was started in July and August, I913, and was completed in April and May of the following year. Four additional barges of this kind were finished in 1916.

The Panama Canal Record of October 25, 1916, refers as follows to some severe treatment which two of these barges withstood successfully:

"At the time of the blowing up of the cofferdam behind which the pontoons were built the surface of the water in the entrance basin was about $15 \mathrm{ft}$. below the mean tide level. The gap made by the explosion did not allow the water to pour in from the sea until the tide rose. The stream which broke over the dam at high tide cut an increasing channel in the earth, resulting in a strong inrushing current sufficient to make the barges part their moorings and circle about the basin. In so doing one of them struck a fender pile and broke it at a point about $20 \mathrm{ft}$. below the butt, where its diameter was about 12 in. The barge groaned under the impact, and one of the end timbers was sheared off, dragging its anchor bolts through the concrete and causing it to crack. This damage was above the water line. In other respects the pontoon was uninjured. The two pontoons collided once in their course around the basin, but this did no damage to either." 
CONCRETE BARGES AT BALTIMORE, MARYLAND

While harbor engineer of Baltimore, Md., Oscar F. Lackey, developed and patented a system of concrete barge construction. In I9II, his system was applied to building a concrete scow for the Arundel Sand \& Gravel Co., of Baltimore. This holds $5 \mathrm{I} \frac{1}{4}$ tons of fresh water and in addition, can be used for transporting such materials as sand and stone. Originally designed to carry 86 tons, it has at times been overloaded with 92 tons without damage. It is 50 feet long, 22 feet wide, and has a depth of 7 feet. Its bottom, walls and deck are 3 inches thick. When this scow was finished, a test was made to determine its strength. This consisted of dropping a 6-ton load into the hull. No damage resulted and the scow was immediately put into service. As a result of this experimental construction for the Arundel Sand \& Gravel Co., a 500-ton concrete scow was built in 1912 , after the same method, by the Furst Concrete Scow Construction Co., of Baltimore, and completed in four months. The hull was built between forms and a very rich concrete mixture used, the work being done section by section.

CONCRETE SHIPS IN CALIFORNIA

In Igio, there was constructed at San Francisco, a concrete scow

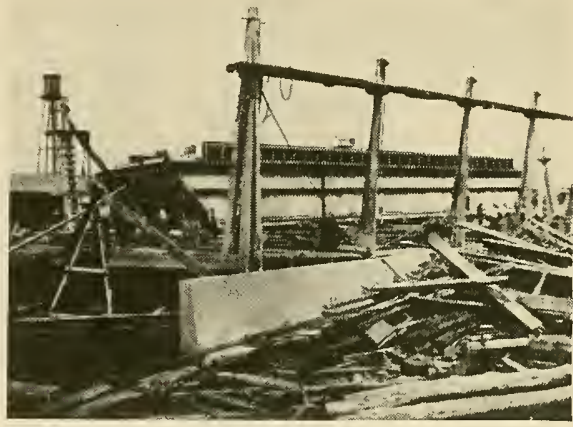

Concrete Scow Built in 1912 by the Furst Concrete Scow Construction Co., Baltimore.

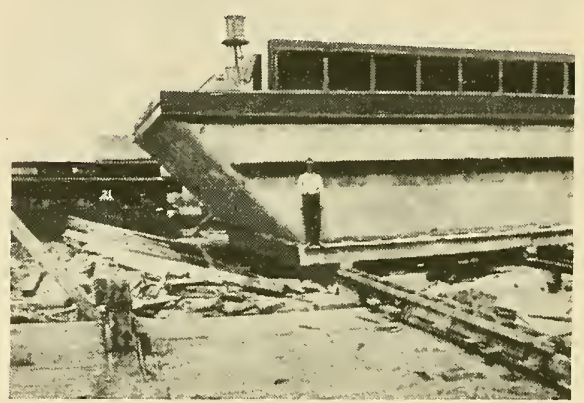

The Furst Scow on the Ways.

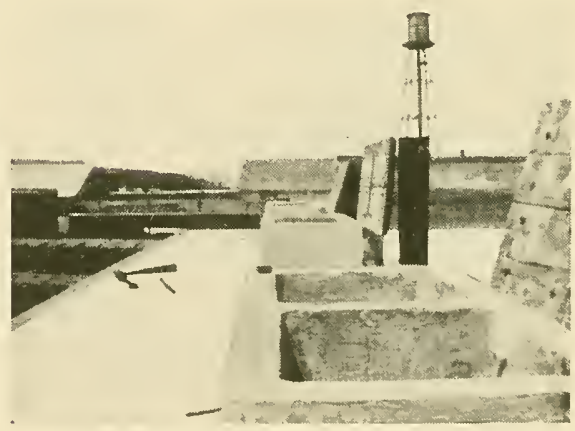

View Showing Hatches on the Furst Concrete Scow. 
of 525 tons capacity. Bulkheads were spaced 6 feet apart in each direction, totaling 26, 160 cubic feet of locked air space, thus making it practically unsinkable. The scow is 100 feet long, 30 feet wide and 7 feet deep.

\section{Arindel Savid Gravel Gompany}

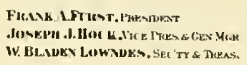

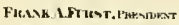

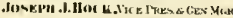

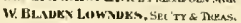

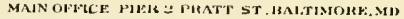

HAETMOHE, MD. July 2nd, 1917.

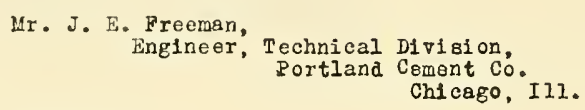

The ascond one we built was wrecked in a storm we had some fow years ago by breaking away from the wharf at Sparrows Point and being washed ashore on a stone pile wo.g loft high and dry, the stone breaking through bor bottom.

The third is being worked dally by the Raymond Concrets file company of this city.

In the three or four years that we have used the flrgt large lighter that was built we have never had occaslon to use a eyphon to pump her out the same as you have to do almost dally with wooden lighters.

These lighters can bo seor at Baltimore and we shall be very glad to take anyone aboard whom you might send here.

Yours very truly,

AFUNDEL SAND APD GRAVELOCOXPANY.

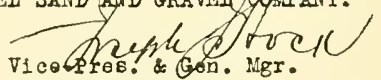

\section{0-TON CARGO VESSEL UNDER CONSTRUCTION} AT SAN FRANCISCO

Reference has already been made in this booklet to an article by Allen Hoar, C. E., in Marine Engineering, for July, 1917. The design presented by Mr. Hoar with this article contemplates a fleet of concrete barges, each 120 by 28 by 8 feet, capable of carrying 400 tons of cargo, between various bay and river points around San Francisco. Loaded light, the draft of these barges will be 2 feet 7 inches and the displacement 258 tons. The hull will be divided into watertight compartments by 


\section{O N C R E TE S H I P S}

MORTON O NULL

Dittgourga

ealtimone

HENNETH $X$ KIPWAN,
ManmeLL m unson

NR MOTER

h O RAYMONO

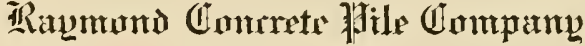

NEW YORK OFFICE

HO CEOAR ETREET

Chicago office
KANSAS CITY

- trovis

pontLano

BALTIMORE, MD., July 16 th, 1917 .

Mr. J.E. Froman, Fingineer.

Teohnical Division.

Portland Cement Assoolation,

111 W. Washington 9 t. *

Chloago, I11.

Dear S1r:

We have your letter of the 13 th inst. In reference to

reinforced concrete ecow whlch we have in our service.

We are pleased to advise you that this acow has been

very antiafactory in every respect and there has not been a dollar's

worth of ropairs since this scow was placod in comnission, about three years ago.

We have taken the 11 berty of referring your letter to Mir. Ososr F.Lacikey former Harbor Englneer of Baltimore, who built and owns this bargo. H18 present addross $18 \%$ The Motsinger Dovice MfG. Co., Iafayette, Indiana.

Yours very truly,

BAYMOND CONCRETE PILE CONPANY.

$\mathrm{KKK} / \mathrm{MM}$ District lianager.

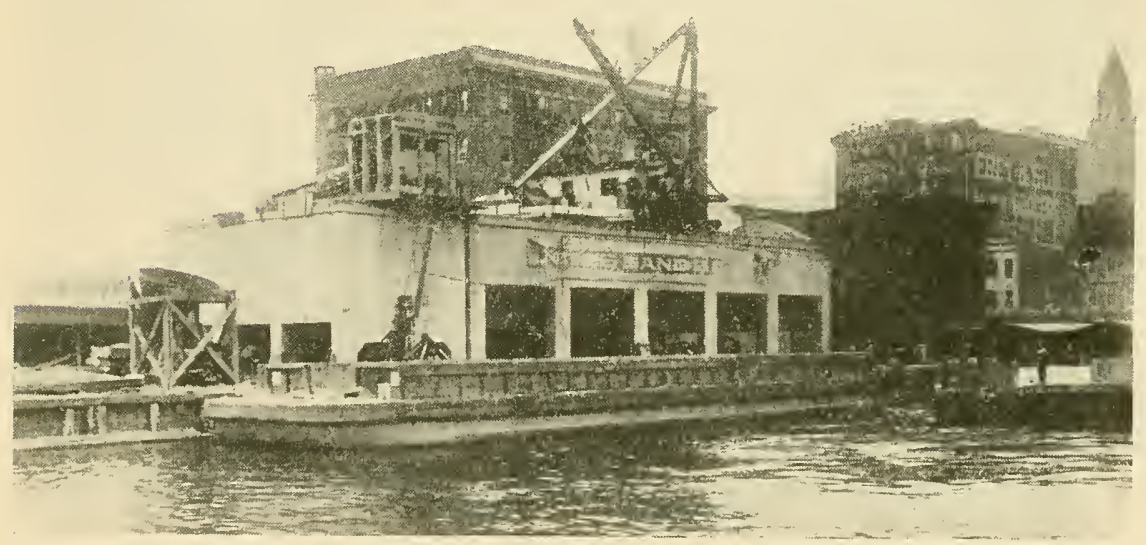

Concrete Lighter of the Arundel Sand and Gravel Co., Baltimore, in Service July, 1917, referred to in the letter on preceding page. 
longitudinal and transverse bulkheads, while wood timbers will serve as guards to protect the barge from injury by collision. In connection with Mr. Hoar's article in Marine EngineERING, the following table of comparisons appeared:

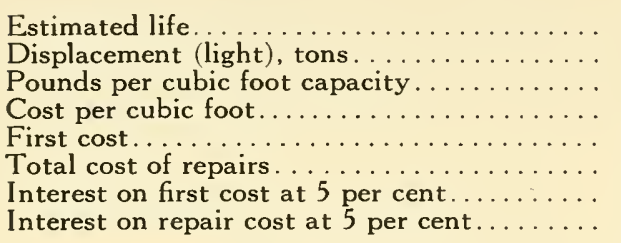

Total cost.

Total annual cost $\ldots \ldots \ldots \ldots \ldots \ldots \ldots$

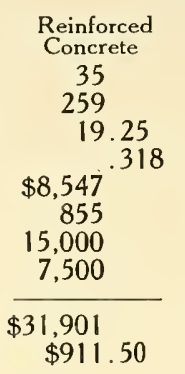

Wood

15
135

135

10

\begin{tabular}{|c|c|}
\hline $\begin{array}{r}\$ 8,171 \\
2,432 \\
6,128 \\
912\end{array}$ & $\begin{array}{r}\$ 18,466 \\
1,847 \\
23,082 \\
11,541\end{array}$ \\
\hline & $\$$ \\
\hline
\end{tabular}

Because of knowledge and experience available to prove what may be expected from concrete barges, a group of San Francisco capitalists are said to have advanced $\$ 200,000$ this year (1917) to finance the building of sea-going vessels of concrete. Allan McDonald, of McDonald \& Kahn, San Francisco, has developed plans for a 4,500-ton cargo vessel that will be 300 feet long, 46-foot beam, have 24 -foot draft, and a hull 6 inches thick. In constructing this vessel it is proposed to weld the reinforcing together, thus reducing the quantity of steel required to a minimum by avoiding waste from laps and bolting otherwise necessary. A study of the design proposed for this ship indicates that the reinforcing which will be used weighs less than bolts needed in a wood ship, and that the hull will weigh less than that of a wood ship. It is planned to build this vessel complete in go days; 2,500 horse-power Turbine engines equipped with reduction gears are to be used as motive power.

\section{CARL WEBER PATENTS}

Not long ago a system of concrete ship construction was invented and patent applied for by Carl Weber, a well-known concrete engineer, and president of the Cement Gun Construction Co., of Chicago. Mr. Weber proposes to use a concrete or steel framework and cover this with a number of layers of reinforced concrete, which will be placed by his "Tector" process, which uses a machine that applies concrete by means of air pressure in a manner somewhat similar to the Cement Gun, except that in this patented method the hydration process is divided into two distinct stages, which results in elimination of sand pockets in the hull and in a more uniform and denser concrete.

He also employs a special mixing process in which the mixture is thoroughly kneaded after pre-hydration. The result is a high grade waterproof concrete for which the trade name "Torcrete" has been adopted. 


\section{ERRATA}

The table on page 28, taken from Marine Engineering, is evidently in error with respect to the following items, which should be as follows:

\begin{tabular}{|c|c|c|}
\hline $\begin{array}{l}\text { terest on repair cost at } 5 \text { per cen } \\
\text { Total cost } \ldots \ldots \ldots \ldots \ldots \ldots \\
\text { Annual cost } \ldots \ldots \ldots \ldots \ldots \ldots\end{array}$ & $\begin{array}{c}\begin{array}{c}\text { Reinforced } \\
\text { Concrete }\end{array} \\
\ldots 750 \\
\$ 25.152 \\
\ldots \ldots 718.63\end{array}$ & $\begin{array}{c}\text { Steel } \\
\$ 1,154 \\
\$ 44,549 \\
\$ 1,781.96\end{array}$ \\
\hline
\end{tabular}




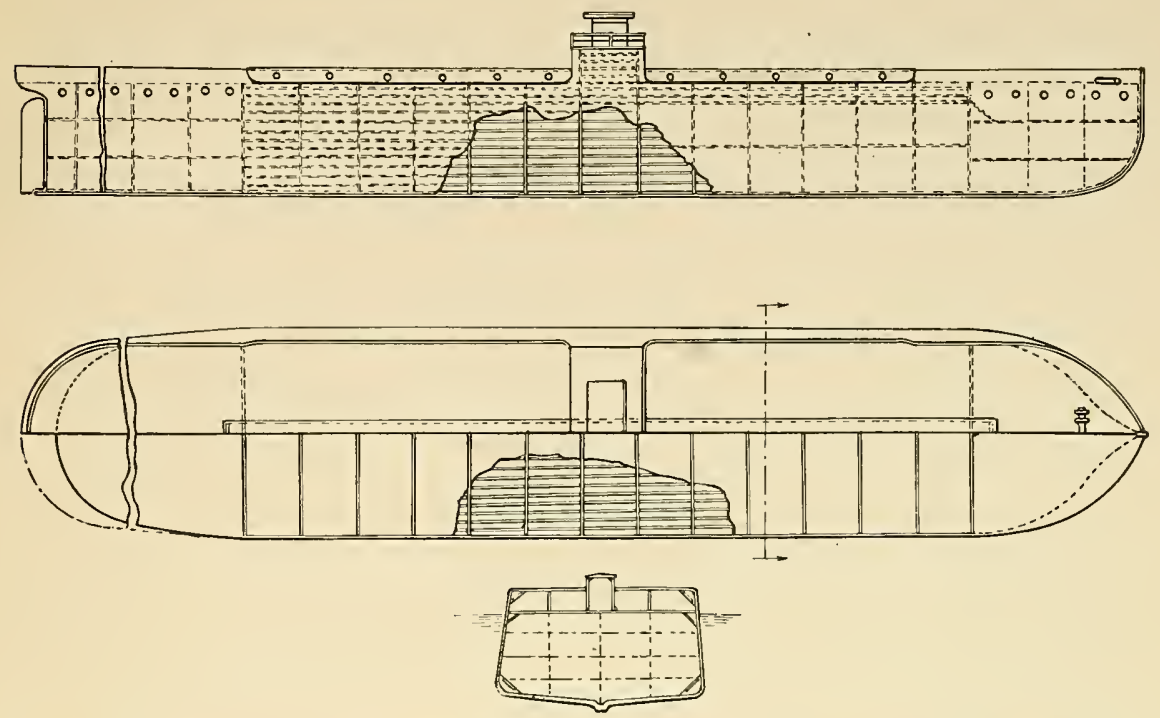

Plans for Concrete Ship Proposed for Construction After the Methods Suggested by Carl Weber.

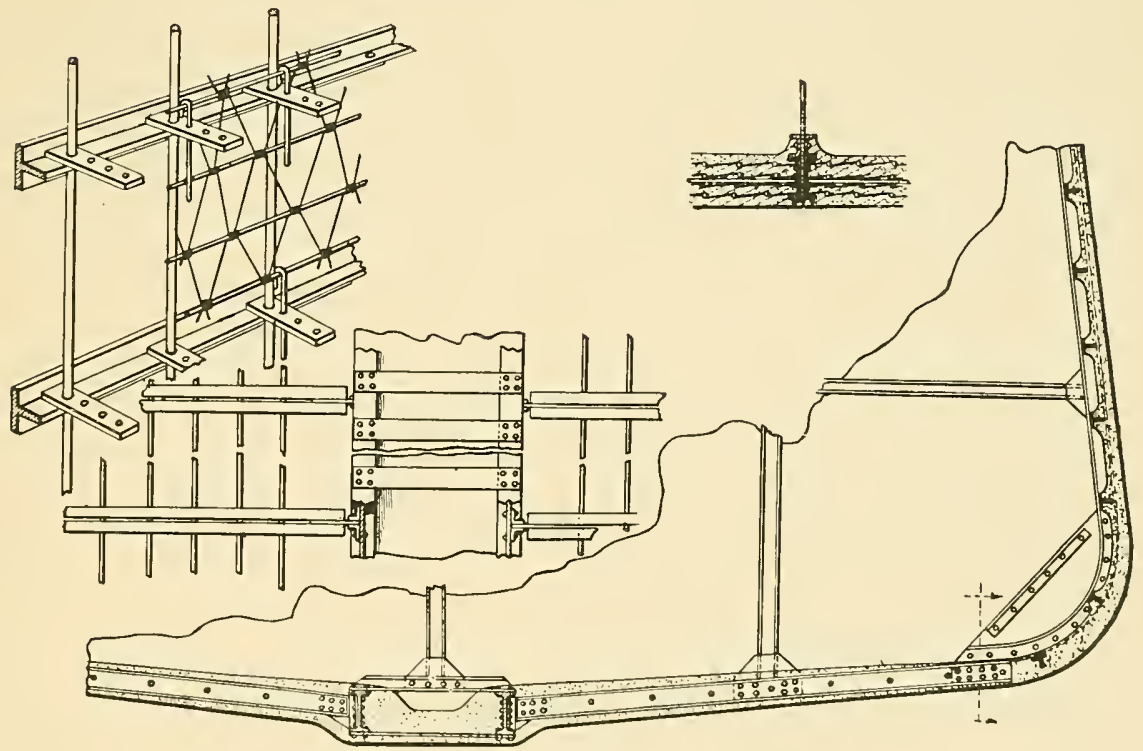

Some Details of Carl Weber's Patented Concrete Ship Construction.

Page Twenly-nine 
The method proposed by Mr. Weber gives promise of solving the problem of rapid construction, because it practically eliminates form work, makes a very dense and strong concrete, is capable of adapting itself to the requirements of different types of construction, and of forming the most difficult streamline bodies of ships correctly and at a low cost.

The hull will be built up by a series of laminations varying in number and thickness according to the pressures developed at the different depths and also according to the purpose for which the vessel is to be used. By means of Mr. Weber's patented spacing bars, the reinforcement may be accurately located and the thickness of hull carefully determined without elaborate provision for checking the work. For this reason less skilled labor is required, and as the bars in themselves provide a measure of the thickness of the hull, no time is lost in checking this up.

The fact that Mr. Weber proposes to use a steel skeleton for larger vessels makes it possible to reduce the weight to a minimum and at the same time make use of standard structural steel shapes that are now more easy to obtain than steel plates. Inasmuch as the steel skeleton is very similar to skyscraper erection, skilled labor of this class may easily be obtained. It also makes for its quick erection because the time consumed in steel ship construction (and the largest part of the cost) goes in the work of riveting and caulking the plating.

E. Lee Heidenreich, a well-known consulting engineer specializing in concrete construction, and of the Heidenreich Engineering Co., Kansas City, Mo., has devoted some thought to the possibility of concrete for shipbuilding and as one means of using the material proposes a design for a concrete ship shown in the tentative sketches on pages 18 and 19. In referring to this design, Mr. Heidenreich says:

"The hull is composed of five vertical longitudinal trusses, three horizontal trusses consisting of one deck and two floor trusses, and in addition a series of transverse bulkheads which may be pierced by small or large openings as desired. It can be seen that stresses in this construction are determinable and that the resisting moments are largely met by Tee Beam constructions to take care of the primary stresses and their recoil.

"During the submarine activities the watertight compartments in the sides of the hull and in the bilge might be filled with sawdust if there be any virtue to such construction; the necessity of which, however, I am inclined to discount.

"The sketch submitted being entirely schematic, the construction load water line as well as the scale of displacement from light to load water line has not been attached, but any engineer well informed on the mechanics and kinetics of shipbuilding and with a knowledge of the modern calculations of reinforced concrete on the basis of allowable stresses and the special materials employed, will with ease be able to furnish or check the necessary calculations.

"If a hull like this otherwise be considered satisfactory for a 5000-ton transport, it would require some 3000 cubic yards of reinforced concrete which for a number of vessels could be readily produced at $\$ 20$ per cubic yard or $\$ 60,000$ for the bull. A steel hull of the same capacity would weigh some 1500 tons and cost probably $\$ 150$ a ton or $\$ 225,000$. The concrete hull would take approximately 90 days for construction while the steel hull hardly could be finished, at the present steel market, in 15 months. 
"Naturally, marine engineers and shipbuilders would improve upon the construction by adding the required fore and after and middle decks as well as the correct line of the square and cant bodies.

"It goes without saying, that some of the transverse bulkheads can be reduced to strengthening ribs along the vertical hull and center longitudinal bulkhead as well as act as deck beams. All I maintain is that, with some modifications of the lines of the hull required, I can build same in reinforced concrete by means of sliding forms with great economy in costs and time of construction."

Mr. Heidenreich's long, well-known standing as a designing engineer in the application of concrete to structural requirements, warrants that his opinions be given the consideration to which they are entitled.

In a letter addressed to the editor of MARINE ENGINEERING, and which appeared in its April, 1917, issue, T. L. E. Haug, of the Union Iron Works Co., Alameda, Cal., says, in reference to concrete ships:

"It has been argued that, owing to the alternating nature of the stresses to which a ship's structure is subjected in heavy weather the structural material should be equally adapted, as is steel, to carry tensile or compressive loads. Hence, for equal strength, the reinforced concrete ship would have to have as much steel as the ordinary steel ship, the concrete being valueless in tension, so that the concrete would be just so much extra weight to decrease the carrying capacity of the vessel."

Those who argue as above, however, lose sight of the following facts:

1. The present steel ship does not show an efficient use of the structural materials. Rivet holes, for the attachment of framing to the shell and beams or bulkheads to decks, cut away from 10 to 25 per cent of the strength of shell and deck plating. In a reinforced concrete ship it would appear quite feasible to make joints of the steel reinforcement with little or no loss of tensile strength. Furthermore, the steel ship has an excess of strength in certain parts, as a matter of constructional necessity or convenience, but which would not have to be provided in a reinforced concrete ship. In the latter, the bulk of the steel could be placed just where required, thereby effecting great economy in its use without affecting the strength of the structure.

2. The present steel ship must be constructed with a large excess of material to allow for future corrosion and give the vessel a reasonable life. Such excess would be unnecessary with the steel protected from corrosion, as in a reinforced concrete vessel.

The time will doubtless come when, owing to the exhaustion of good iron ore deposits, etc., the price of steel will increase to a point which will force its more economical use and accelerate the development of the concrete ship.

\section{Application of Concrete to Shipbuilding}

\section{SOME FUNDAMENTAL REQUIREMENTS}

HIP hulls must be made of a material that is stiff enough to prevent $\checkmark$ buckling between ribs. Concrete will accomplish that end. It can be shaped to conform to the lines required and can be finished so smooth that skin friction will be reduced to a minimum and sea growths will find no opportunity for attachment.

Concrete in its plastic state lends itself to any shape. There is no joiner work required as with wood. Jars can loosen no rivets. Reinforced concrete uses steel most effectively. 
Speedy construction is possible because the skeleton of reinforcement may be quickly placed and the ship launched as soon as sufficient hull has been finished to float the unloaded vessel.

Sand, stone, cement, steel reinforcing bars and structural steel shapes are on the market and may be obtained promptly, therefore the materials required for concrete ship construction are readily available.

Most of the labor that is needed to build concrete ships is of the cheaper grade. Expert supervision is needed on any kind of ship construction but the number of skilled artisans required for concrete shipbuilding is small.

Caulking, heavy form work and bracing, fitting of plates and shaping of planking are entirely eliminated in concrete ship construction.

As the time required to construct a sufficient portion of the hull to permit floating the vessel is very short, it is possible to make use of drydock facilities, allowing the vessel to float as soon as possible and then to bring up materials on scows and barges, thereby materially lessening the amount of handling and increasing speed of construction.

\section{ADVANTAGES OF CONCRETE SHIPS}

Concrete ships will prove they have many advantages. Some of these will be apparent to anyone, while others will readily appeal to those having shipbuilding experience.

Among the many reasons why concrete fits shipbuilding requirements are the following:

Concrete ships are fireproof.

Wood-boring worms cannot attack the hull.

Concrete ships require practically no maintenance.

Construction methods are economical and the cost is low.

Concrete ships can be built quickly.

Concrete ships will neither rot nor rust.

Caulking, painting and similar maintenance of the hull is unnecessary.

Concrete ships will withstand very rough usage.

Materials required may be obtained readily anywhere at low cost.

Less labor is required and cheaper labor may be employed.

There is no likelihood that the hull of a properly designed concrete ship will buckle.

Because of the smooth surface and the absence of angular projections, skin friction is greatly reduced.

Concrete vessels may be floated before completion.

Concrete vessels are lighter than similar ones of wood.

Barnacles and other sea growths find conditions unfavorable to their growth.

\section{AMERICAN INGENUITY CAN DO 1T}

In 1909, the United States occupied such an insignificant place in the shipbuilding world that the output of our yards fell below those of Japan. In that year, England led by producing 76 per cent of the world's bottoms. Germany was a poor second; Japan a worse third. 
American ingenuity and enterprise must be and will be brought to bear to supply the world with ships. Suitable lumber and timber are not quickly obtainable. Steel mills are loaded with work. The shipbuilding material that can be obtained in ample quantities at reasonable prices is concrete. It has been tried and found satisfactory.

That the ways in which construction methods must be planned and executed when concrete is the shipbuilding material used will differ some from methods involved with other materials, is true. New problems will arise, but these can be solved, as fully demonstrated by the various examples presented in this booklet.

All that remains is for energetic and far-sighted marine engineers, and shipbuilders and designers in concrete to work together in applying the knowledge and experience with concrete in other construction fields, to the requirements of shipbuilding, so that this excellent construction material may be made available for the present need.

\section{PATENTS FOR CONCRETE SHIPS}

Below will be shown a list of patents that have been taken out to cover various methods of using concrete in ship-building:

\begin{tabular}{|c|c|c|}
\hline $\begin{array}{l}\text { Patent No. } \\
906,846\end{array}$ & $\begin{array}{c}\text { Patentee } \\
\text { Lorenzo D'Adda }\end{array}$ & $\begin{array}{c}\text { Date of Issue } \\
\text { Dec. } 15,1908\end{array}$ \\
\hline $\begin{array}{l}920,046 \\
933,314\end{array}$ & $\begin{array}{l}\text { Carlo Gabellini } \\
\text { O. F. Lackey }\end{array}$ & $\begin{array}{l}\text { April 27, } 1909 \\
\text { Sept. 7, } 1909\end{array}$ \\
\hline 984,285 & W. E. McNeillie, Jr. & Feb. 14, 1911 \\
\hline 991,780 & A. Holin & May 9,1911 \\
\hline $\begin{array}{l}1,008,801 \\
1,018,488 \\
1,090,349\end{array}$ & $\begin{array}{l}\text { G. E. Elia } \\
\text { J. T. Gorsuch } \\
\text { H. E. Smith }\end{array}$ & $\begin{array}{l}\text { Nov. 14, } 1911 \\
\text { Feb. 27, } 1912 \\
\text { Mar. 17, } 1914\end{array}$ \\
\hline $1,209,159$ & S. D. Hendricks & Dec. 19,1916 \\
\hline
\end{tabular}

Description

Reinforced Concrete Armor for Battleships.

Float of Reinforced Concrete.

Concrete Scow having concrete hull and metal frame.

Concrete boat reinforced with angle irons and wire mesh.

Floating body with reinforced concrete frame and hull.

Concrete protection for ships.

Reinforced concrete scow.

Boat with reinforced concrete hull.

Reinforced concrete unit construction for barge and ships. 


\section{Bibliography}

$\mathrm{M}$

$\mathrm{UCH}$ of the information presented in this booklet has been gleaned from articles that have appeared in various publications, to which acknowlegment is hereby made. Although a summary of the more important of these articles appears in this booklet, those considering the building of concrete ships may be interested in obtaining the fullest available information on the subject. For this reason the following bibliography of literature upon the use of concrete in boats, barges, etc., has been prepared:

American Marine Engineer, The (Chicago), December, I9I6 Beton u. Eisen (Berlin), January 8, I909, page I4

$$
\begin{aligned}
& \text { " . ". ". April 20, I9I2, page I56 } \\
& \text {. " . " . " . February I3, I9II, page } 93 \\
& \text { ". }
\end{aligned}
$$

Canadian Engineer (Toronto), March 9, 1911, Vol. 20, pages 4I4-15

Cement (New York), May, 1903, Vol. 4, No. 2, page I23

Cement Age (Detroit), December, I910, Vol. i I, No. 6, page 405

Cement Era (Chicago), April, 1915, Vol. 13, No. 4, page 44

$\begin{array}{lll}. . & . & \text { " } \\ . . & \text {.. } & \\ . & \text {.. }\end{array}$

April, 1915, Vol. 13, No. 4, pages 44-45

February, I9I I, Vol. 9, No. 2, pages 26-28

February, I9II, Vol. 9, No. 2, page 25

Cement Record (Kansas City, Mo.), December, I909, Vol. 2, No. 6, pages I-5

Cement World (Chicago), August, I9I , Vol. 5, No. 5, page 27

Concrete (Detroit), Vol. 9, No. 2, February, I909, page 7 I

.. $\quad$ ". October, I9I6, Vol. 9, No. 4, page IIo

May, I9o9, Vol. 9, No. 5, pages 36--38
Concrete Age (Atlanta), November, I9I6, Vol. 25, No. 2, page II

Concrete-Cement Age (Detroit), September, 1915, Vol. 7, No. 3, page 92

Concrete Engineering (Cleveland), December, I9I0, Vol. 5, No. I2, page 298

Concrete $\mathcal{E}$ Constructional Engineering, London, October, I9I6, Vol. II,

No. Io, page 566

Concrete 8 Constructional Engineering, London, May, I9I I, Vol. 6, No. 5. Engineering (London), April 20, I9I7, page 381

Engineering and Contracting (Chicago), September I8, I9I2, Vol. 38 , No. I2, pages 3i6-3i

Engineering News (New York) March 6, I9I3, Vol. 69, No. I0, page 466

$\begin{array}{llll}. . & . . & . & \text { July } 28,1910, \text { Vol. } 64, \text { No. } 4 \text {, pages } 96-97 \\ . & . . & . & \text { November I6, I9I6, Vol. } 76, \text { No. 20, page } 927 \\ . . & \text {.. } & . & \text { January I4, I9I5, Vol. } 73, \text { No. 2, page } 79\end{array}$


Engineering News, (New York), September 10, I9I4, Vol. 72, No. I2, pages $562-563$

Engineering Record (New York), May 28, I9Io, Vol. 61, No. 22, pages $707-708$

Engineering Record (New York), May 29, I915, Vol. 71, No. 22, pages $684-86$

Engineering Record (New York), December 23, I916, Vol. 74, No. 26, pages $779-780$

International Marine Engineering (New. York), July, I9I7, page 301 Le Yacht (Paris), Vol. 31, page 668

Letter of American Consular Service, Christiania, Norway, to Portland Cement Association, dated October 28, 1916

National Association of Cement Users, Proceedings, Vol. 6, I9Io, pages 82-83 New York Evening Sun (New York), September 25, 1916

Scientific American (New York), December I9, I9I4, page 505 Shipping Illustrated (New York), June 23, I9I7, page 270 The Times (London), Engineering Supplement, May 25, 1917 Tonindustrie Zeitung (Berlin), Vol. 32, page 354 


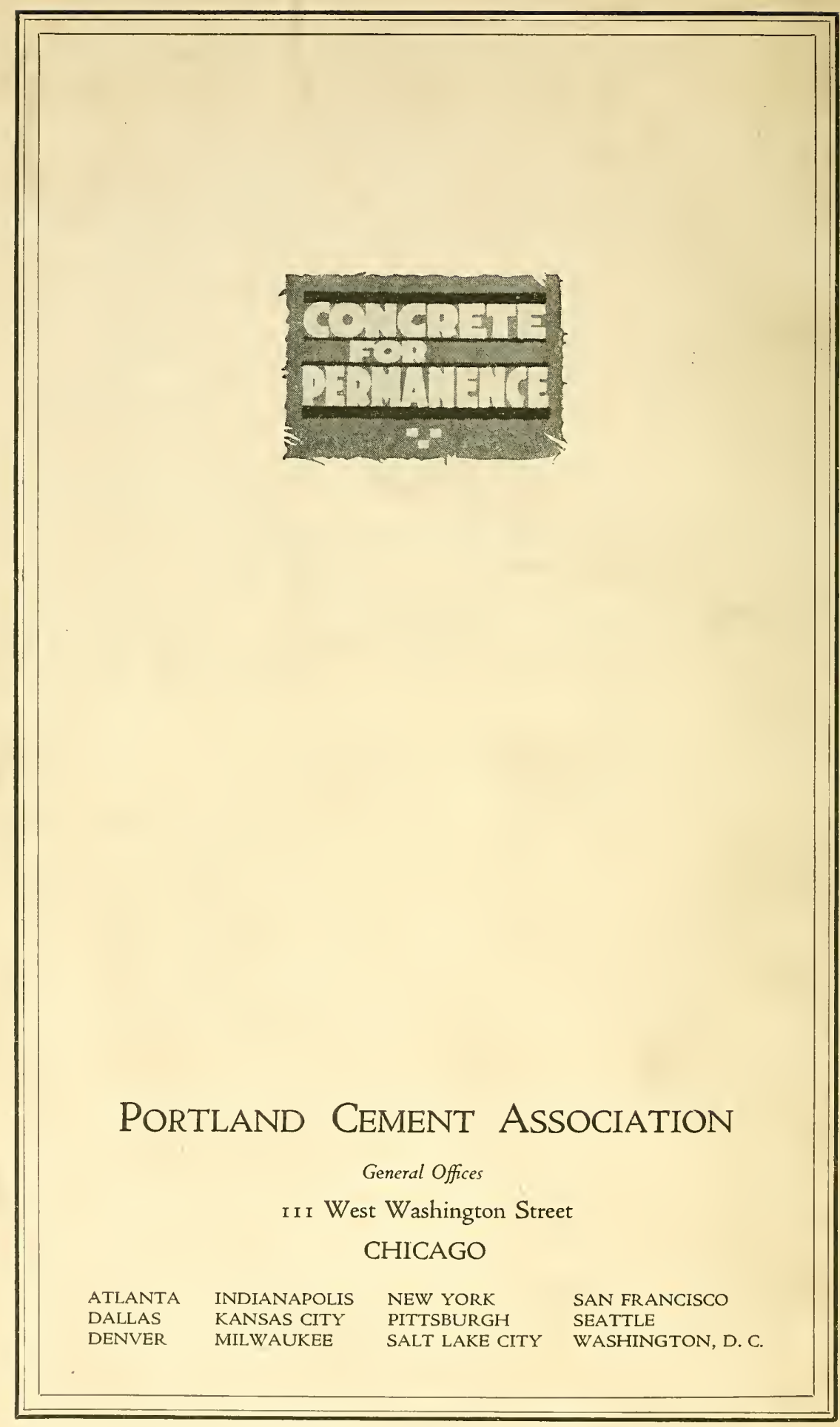





